\title{
Review: Diagnostic, prognostic and predictive relevance of molecular markers in gliomas
}

\section{Sebastian Brandner MD FRCPath ${ }^{1}$ and Andreas von Deimling ${ }^{2}$ MD}

1) Division of Neuropathology, The National Hospital for Neurology and Neurosurgery, University College London NHS Foundation Trust and Department of Neurodegeneration, UCL Institute of Neurology Queen Square,. London WC1N 3BG

2) Department of Neuropathology University of Heidelberg, and Clinical Cooperation Unit Neuropathology, German Cancer Research Center, DKFZ and DKTK, im Neuenheimer Feld 224, 69120 Heidelberg

\begin{abstract}
:
The advances of genome-wide "discovery platforms" and the increasing affordability of the analysis of significant sample sizes have led to the identification of novel mutations in brain tumours that became diagnostically and prognostically relevant. The development of mutation-specific antibodies has facilitated the introduction of these convenient biomarkers into most neuropathology laboratories and has changed our approach to brain tumour diagnostics. However, tissue diagnosis will remain an essential first step for the correct stratification for subsequent molecular tests and the combined interpretation of the molecular and tissue diagnosis ideally remains with the neuropathologist. This overview will help understanding the pathobiology of common intrinsic brain tumours in adults and help guiding which molecular tests can supplement and refine the tissue diagnosis of the most common adult intrinsic brain tumours. This article will discuss the relevance of $1 p / 19 q$ codeletions, IDH1/2 mutations, BRAF V600E and BRAF fusion mutations, more recently discovered mutations in ATRX, H3F3A, TERT, CIC and FUBP1, for diagnosis, prognostication and predictive testing. In a tumour-specific topic, the role of MAPK pathway mutations in the pathogenesis of pilocytic astrocytomas will be covered.
\end{abstract}

\section{Key words}

Astrocytoma, pilocytic astrocytoma, oligodendroglioma, oligoastrocytoma, glioblastoma, BRAF V600E mutation, BRAF fusion mutation, 1p/19q codeletion, IDH1 mutation, IDH2 mutation, ATRX, CIC, H3F3A, TERT, FUBP1 mutations, MGMT promoter methylation, biomarker.

\section{Introduction}

The central purpose of tissue-based diagnosis is to advise clinicians and patients about the most adequate treatment, by informing them about the nature of the lesion and the prognosis of the disease. The fundament of the WHO classification of brain tumours is the distinction of grades, which since its introduction in 1979 has used a scheme representing a 
"malignancy scale" ranging across a wide range of CNS neoplasms [1]. As a rule of thumb, patients with grade II tumours survive more than 5 years, whilst patients with grade III tumours survive 2-3 years and the survival of patients with WHO grade IV tumours depends on the availability of effective treatment. Untreated grade IV tumours are rapidly fatal [1]. In gliomas, the grade is largely based on the presence of certain morphological features including cellular and nuclear atypia, mitotic activity, microvascular proliferation and necrosis [2]. The nomenclature ("typing") of brain tumours according to the WHO classification is still largely based on the resemblance of tumour cell shape, morphology and localization to those of differentiated cells of the brain or expression of glial or neuronal proteins. This has continuously been supplemented by biomarkers that more reliably determine proliferation and more precisely define the differentiation of tumour cells. A significant advance in molecular glioma diagnostics was the discovery of the relatively consistent deletion of chromosomal arms 1p and 19q in oligodendroglial tumours [3-5] (Fig. 1) but it took more than a decade until the predictive and prognostic value was corroborated [6] and verified in randomised clinical trials $[7,8]$. Although generally recognised as an essential diagnostic tool, $1 p / 19 q$ testing is still not as widely available as desirable, mainly because it is a comparatively laborious and thus expensive test method. It will be important that the Neuropathology community encourages also smaller centres to make a case to provide this test locally. More recently, next generation sequencing and methylome arrays became potentially useful diagnostic tests that can complement glioma diagnostics.

A major breakthrough in the diagnosis of gliomas was the discovery of the mutation in the IDH1 and 2 genes in astrocytomas and oligodendrogliomas. Antibodies, generated against the most common $I D H$ mutation (IDH1 $1^{\mathrm{R} 132 \mathrm{H}}$ ), has within less than a year after discovery become an affordable test for a biomarker with diagnostic and predictive value $[9,10]$. The retrospective analysis of samples of patients with astrocytomas and oligodendrogliomas by large scale genomic methods subsequently identified further genes that were consistently altered, e.g. CIC and FUBP1 [11, 12] in 1p/19q deleted oligodendrogliomas or ATRX mutations in $I D H$ mutant, $1 \mathrm{p} / 19 \mathrm{q}$-preserved astrocytomas.

The discovery of new biomarkers and their mapping against clinical outcome highlights the importance of the full integration of the tissue diagnosis with biomarkers, and underpins the continued importance of the neuropathologist in giving a full, integrated opinion [13]. These "Haarlem Consensus Guidelines for Nervous System Tumor Classification" suggest that some entities will require molecular information to provide an "integrated" diagnosis, which is based on several layers comprising (i) the integrated diagnosis as top layer, followed by (ii) histological classification, (iii) WHO grade, and (iv) molecular information.

The identification of driver mutations in glial or glioneuronal tumours, such as IDH1, IDH2, H3F3A or BRAF point or fusion mutations also widens our understanding of the pathobiology and histogenesis of these tumours and we will have to accept that many of these tumours may represent part of a spectrum of histological phenotypes arising from a defined mutation in the stem/progenitor compartment in the brain [14-18] rather than being predominantly morphologically defined entities that may lack a biological justification. This is likely to have an impact on our approach towards diagnosing brain tumours, and one can be hopeful that ambiguous diagnoses, such as oligoastrocytomas or the glioblastoma (GBM) with oligodendroglial component will disappear in favour of molecularly endorsed entities [13, 
19]. Recent consensus meetings have underpinned this notion and highlight the growing importance of molecular markers to support a molecularly enhanced neuropathological diagnosis but there is a lively debate to what extent to integrate (or rely on ) molecular data $[13,20]$.

This review will present data to justify molecular testing of gliomas and will highlight the diagnostic value for tumour classification, and predictive/prognostic values of the molecular tests:

1) What is the benefit of $1 p / 19 q$ and $I D H$ molecular testing for the patient?

2) Is there a benefit to use the markers ATRX, FUBP1, H3F3A, CIC and TERT in glioma diagnostics?

3) What is the biological and diagnostic role of BRAF V600E and BRAF fusion gene mutations in the context of low grade CNS tumours?

4) What is the predictive and prognostic value of the MGMT promoter methylation in high grade gliomas?

\section{Incidence and survival rates of common glial tumours}

Astrocytic and oligodendroglial tumours (WHO Grades II and III) have an annual incidence of 10.1 new tumours per million population in Western countries, and GBMs have an incidence of 35.5 per million and that of all intrinsic brain tumours is 52.7 per million [21, 22]. Extrapolated for the UK (population 63.7 million), this equates to 640 new oligodendrogliomas and astrocytomas in adults, and $\sim 2,260$ GBM annually. Pilocytic astrocytomas are less common with 3-4 per million, or approximately 220 cases annually in the UK and both the pleomorphic xanthoastrocytoma and the subependymal giant cell astrocytomas are very rare with 2 and 1 cases per million population annually (14 and 7 cases annually in the UK).

Survival rates for pilocytic astrocytomas are generally excellent ( $96 \%$ at 10 years), whilst the diffusely infiltrating gliomas have a less favourable prognosis with median survival times of 5.6 years for WHO Grade II astrocytomas, 1.6 years for anaplastic astrocytomas (WHO Grade III) and 0.4 years for GBM (WHO Grade IV) [22-24]. WHO Grade II oligodendrogliomas have a median survival time of 11.6 years and anaplastic oligodendrogliomas 3.5 years. Of note these epidemiological data were not validated by molecular parameters.

\section{Codeletion of chromosomal arms $1 p$ and $19 q$}

Summary: The codeletion of $1 p / 19 q$, in the past often also referred to as combined loss of chromosomal arms ( $\mathrm{LOH}$, loss of heterozygosity) is a significant predictor of outcome for patients with tumours of oligodendroglial and oligoastrocytic histology. 1p/19q codeletion is mainly observed in classical oligodendrogliomas (Fig. 1, 2A). Response to first line procarbazine, CCNU, and vincristine (PCV) or to temozolomide (TMZ) chemotherapy strongly correlated to loss of $1 p[25,26]$, whilst response to second line alkylating treatment is modest even in tumours with $1 p / 19 q$ codeletion.

Prognostic and predictive value: The $1 p / 19 q$ status is prognostically highly relevant. It is associated with longer progression free survival and better chemotherapy response. This was reported and validated in multiple studies [25, 27-31]. Patients with tumours lacking $1 p$ 
and $19 q(46 \%)$ compared with those with preserved $1 p$ and $19 q$ had longer median survival times ( $7 \vee 2.8$ years, respectively; $p<0.001$ ) and longer progression-free survival was most apparent in this group. In current clinical practice patients with gliomas (grade II/III) harbouring a $1 p / 19 q$ codeletion are often treated with first line chemotherapy (CT) (temozolomide or PCV) with a high chance of good clinical response. It has been reported that many centres tend to defer radiotherapy (RT) particularly in patients with predicted long-term survival $[32,33]$. CT alone or in combination with RT shows no significant difference for overall survival in some studies [34], but CT/RT shows survival benefit over RT alone in codeleted oligodendrogliomas [35, 36]. In contrast, patients with non-codeleted $1 p / 19 q$ will be usually offered first line RT with or without combined CT due to the limited chance of response to chemotherapy [32]. IDH1/2 mutations (see below) and 1p/19q codeletion are of major prognostic significance for outcome .

Diagnostic value: Histological distinction of oligodendrogliomas from astrocytomas is highly subjective, and there is an established interobserver variability to discriminate astrocytomas, oligoastrocytomas and oligodendrogliomas $[37,38]$. This makes the $1 p / 19 q$ test of indispensable diagnostic value (Fig. 3). Although the test cannot discriminate between oligodendrogliomas and oligoastrocytomas, it will help narrowing down diagnostic options, for example in small, non-representative (but tumour containing) biopsies. It is increasingly recommended, based on molecular evidence to minimise the diagnosis of oligoastrocytomas and to favour a classification into astrocytomas and oligodendrogliomas [19, 39-41]. The diagnostic value of $1 p / 19 q$ tests is further enhanced by the combined use of the biomarkers IDH1, IDH2, ATRX, CIC and FUBP1 (see below, and Fig. 4).

Molecular Mechanisms: Deletions of segments of the chromosomes $1 p$ and 19q are closely associated with the oligodendroglial histological phenotype (Fig. 3A, B, and Fig. 4). Chromosome losses occur in the majority of oligodendrogliomas and are often associated with a pericentromeric translocation of chromosomes 1 and 19 [42, 43] (Fig. 1). The translocation results in a $1 p$ and $1 q t(1 ; 19)$ fused at the centromere $(q 10 ; p 10)$ and a chromosome derivative (Fig. 1). This translocation is unbalanced, leaving the cells with one copy of the short arm of chromosome 1 and one copy of the long arm of chromosome 19. Whilst most cancer translocations involve one of the genes residing near a break- point, and produce a fusion gene product, the $\operatorname{der}(1 ; 19)(q 10 ; p 10)$ breakpoints are in gene-poor centromeric regions and always associated with codeletion [42, 43].

\section{Mutations in isocitrate dehydrogenase genes IDH1 and IDH2}

Summary: Mutations at the codon 132 in the isocitrate dehydrogenase 1 (IDH1) genes, primarily of the IDH1 ${ }^{\mathrm{R} 132 \mathrm{H}}$ type, occur early, with a high frequency, in WHO grade II and III astrocytic and oligodendroglial tumours and in secondary GBMs, which develop from astrocytomas. IDH mutations in gliomas are early, if not initiating events in their pathogenesis, and are associated with several clinically relevant parameters including patient age, histopathological diagnosis, combined 1p/19q deletion, TP53 mutation, MGMT promoter hypermethylation and patient survival [44-48]. 
Prognostic and predictive value: The association between IDH1/2 mutation and a favourable prognosis is better established in high grade gliomas [49-51], whilst the prognostic value in WHO grade II tumours seems is less clear [50,52, 53]. The majority of studies reporting mutant IDH1 as a favourable factor in WHO grade II tumours often include oligodendroglial tumours $[50,52,54]$. Studies comprising low grade astrocytomas only showed no prognostic value of mutant $I D H 1 / 2[55,56]$. The NOA4 trial identified that MGMT promoter methylation is prognostic for patients with IDH1/2-mutant WHO grade III gliomas, but in patients with $I D H$-wild-type tumours, MGMT promoter methylation was predictive for benefit from alkylating chemotherapy [57].

Diagnostic value: Testing of the $I D H$ status is highly relevant for the diagnosis of primary brain tumours. An antibody, specific for the IDH ${ }^{\mathrm{R} 132 \mathrm{H}}$ mutation has been developed in 2009 and is commercially available for diagnostic testing on paraffin sections (Fig. 3) [10, 58, 59]. Using this antibody, $90 \%$ of $I D H$ mutations can be detected [9]. It is recommended to test the remaining $10 \%$ by sequencing (Fig. 3) $[46,60]$. Considering the easy and cost-effective testing by immunohistochemistry, $I D H$ sequencing is not considered an essential routine test in many neuropathology laboratories. However, in selected low grade gliomas in a patient group where IDH mutation status would impact on treatment decisions [46], additional testing of IHC-negative astrocytomas and oligodendrogliomas should be considered [46, 59]. The routine testing for $I D H$ mutations can help differentiating low-grade or anaplastic oligodendrogliomas from other intrinsic neoplasms with focal or entire clear cell morphology, including primary GBM, clear cell ependymomas, neurocytomas or pilocytic astrocytomas with oligodendroglial-like differentiation, and high grade astrocytomas or oligodendrogliomas from "primary GBMs with oligodendroglial differentiation" as described in [9] (Fig. 3, 4).

Molecular Mechanisms: Pathogenic mutations in the IDH genes 1 and 2 were discovered in next-generation sequencing studies of 22 GBM [49]. The analysis led to the discovery of a variety of genes that were not known to be altered in GBMs but importantly these IDH mutations were discovered in secondary GBM. Subsequent studies, first on a wide spectrum of brain tumours [61], and subsequently on selected astrocytic and oligodendroglial tumours [62-67] revealed that this mutations is likely to be a tumour initiating or driver mutation [68] in astrocytomas and oligodendrogliomas, even in the presence of a pre-existing mutation of the tumour suppressor gene $p 53$ [69]. The most common mutation ( 90\%) in glial brain tumours causes a substitution of the amino acid Arginine to Histidine at codon 132 of the $I D H 1$ gene (IDH1 R132H) and together with the rarer mutations in codon 132 renders mutant $I D H$ as useful diagnostic biomarker $[64,70]$. These mutations change the enzymatic activity of the cytoplasmic and peroxysomal IDH1. The same holds true for codon 172 mutations in the mitochondrial IDH2 gene. These homologous enzymes decarboxylate isocitrate to $\alpha$ ketoglutarate $(\alpha K G)$ and this "neomorphic" mutation renders the IDH enzyme to reduce $\alpha$ KG into 2-hydroxyglutarate (2-HG) in an NADPH-dependent manner [71]. The product of this novel reaction, $2-H G$, is a poorly understood metabolite which accumulates to high levels in glioma tissues and it has been suggested that 2-HG enhances proliferation and impairs differentiation [72, 73]. 2-HG can inhibit many 2OG-dependent enzymes, including various histone demethylases and the $5^{\prime}$-methylcytosine hydroxylase TET2. Mutant IDH1 or IDH2 are associated with increased histone methylation, suggesting to cause epigenetic alterations in 
both, DNA and histones, altering gene expression and promoting oncogenic transformation. The presence of an $I D H$ mutation in gliomas leads to a reorganization of the methylome and transcriptome. The hypermethylation of cytosine in the promoter region occurs in CpG islands, where the nucleotide Cytosine is located next to Guanine, separated by one phosphate. Cytosines in CpG dinucleotides can be methylated to form 5-methylcytosine. In this context, hypermethylation represents a change in 5-methyl-cytosine distribution across the genome rather than an overall increase in the total amount of methylation [74]. Subsequently it has been shown that mutant $I D H$ is the molecular basis of the $\mathrm{CpG}$ island methylator phenotype (CIMP) in gliomas, leading to global dysregulation of gene expression [75-77]. The analysis of epigenetic changes in the cohort of The Cancer Genome Atlas (TCGA) identified a subgroup of GBM tumours with highly concordant CpG island methylator phenotype which were strongly associated with $I D H$ mutations [77, 78]. Methylation arrays have also helped identifying novel subgroups of GBMs, with IDH mutant tumours showing a G-CIMP phenotype $[79,80]$.

\section{Further characterisation of gliomas with the biomarkers ATRX, FUBP1, and CIC}

These biomarkers have been recently identified in the context of gliomas and allow for a further diagnostic accuracy and potential stratification for clinical outcome.

\section{ATRX is frequently lost in IDH mutant astrocytomas}

Summary: ATRX loss is a useful biomarker in the refinement of the diagnosis of IDH mutant astrocytomas, and may be used to delineate these tumours from oligoastrocytomas and oligodendrogliomas (Fig. 3, 4) [19, 41]. ATRX and IDH mutant anaplastic astrocytomas have a favourable prognosis compared to anaplastic astrocytomas with IDH mutation only [39].

Prognostic and predictive value: Analysis of ATRX mutations in the "biomarker cohort" of the NOA-04 clinical trial [39] shows a survival benefit of ATRX mutant astrocytomas. The trial compared efficacy and safety of radiotherapy versus chemotherapy with either PCV or TMZ as initial therapy in patients with newly diagnosed, supratentorial anaplastic gliomas (WHO grade III) and examined the clinical relevance of $1 p / 19 q$ codeletion, MGMT promoter methylation and IDH1 mutations in anaplastic astrocytomas [26]. Based on the molecular profiles and the clinical outcome, a modified diagnostic algorithm was proposed, suggesting the terms "molecular" astrocytomas, oligodendrogliomas and GBMs, which may not necessarily directly correspond to histological entities [39, 41]. Introducing ATRX immunohistochemical staining into routine glioma testing may be an important step forward as is may help eliminating the ambiguity of the vaguely defined group of oligoastrocytomas (Fig. 3, 4).

Diagnostic value: ATRX loss occurs almost exclusively in IDH mutant tumours, and ATRX loss and 1p/19q codeletion are largely mutually exclusive (Fig. 4) [39, 41, 81]. Exome sequencing of IDH mutant, 1p/19q intact astrocytomas and oligoastrocytomas showed a high incidence of mutations in the ATRX gene, whilst ATRX mutations are rarely seen in $1 p / 19 q$ co-deleted oligodendrogliomas [41]. Assessment of ATRX loss by immunohistochemical staining captures the majority of mutations, $27 \%$ by IHC vs $33 \%$ by sequencing in grade II tumours and $41 \%$ by IHC vs $46 \%$ by sequencing in grade III astrocytomas in adults [82], indicating that 
the use of immunohistochemical testing in routine neuropathology diagnostics gives a reasonable sensitivity. Another study described a higher mutation rate of $67 \%(10 / 15)$ in grade II astrocytomas, and $73 \%(32 / 44)$ in anaplastic astrocytomas, whilst ATRX mutations are rarely present in primary GBM or pure oligodendrogliomas $(25 \%$ in morphologically diagnosed OII and 7\% in OIII) [12], but only two of the 70 oligodendroglial or oligoastrocytic tumours had an ATRX mutation combined with $1 p / 19 q$ codeletion. Recent, larger studies on more than 400 oligodendroglial and astrocytic gliomas further strengthened the notion of ATRX being a diagnostically useful and important marker [19, 40, 41]. In contrast to paediatric GBM where ATRX mutations occur around a hotspot near the carboxy-terminal helicase domain [15], mutations in adult gliomas are distributed evenly across the gene [12].

Molecular Mechanisms: The ATRX (alpha-thalassemia/mental retardation syndrome Xlinked) protein [83] and its binding partner DAXX (death-associated protein 6) are essential members of a multiprotein complex with a role in regulating chromatin remodelling, nucleosome assembly, telomere maintenance (see TERT paragraph below) and incorporation of Histone H3.3 proteins into the telomeric regions of chromosomes [84]. ATRX loss has been described in pancreatic neuroendocrine tumours, [85], and neuroblastoma [86]. ATRX loss of function mutations were detected also in a small fraction of adult (presumably IDH mutant, "secondary") [87] and paediatric GBM [15].

\section{Markers that facilitate and may in the future complement the diagnosis of oligodendrogliomas: CIC and FUBP mutations segregate with IDH mutation and 1p/19q codeletion.}

A search for candidate genes on chromosomes $1 p$ and $19 q$ by exome sequencing of oligodendrogliomas revealed inactivating mutations in two tumour suppressor genes: (i) homolog of Drosophila capicua (CIC) and (ii) far-upstream binding protein 1 (FUBP1) in 53\% and $15 \%$ of oligodendrogliomas, respectively $[11,12,88,89]$. CIC is located on chromosomal arm 19q (19q13.2) and FUBP1 is located on chromosomal arm $1 p(1 p 31.1)$ and thus $1 p / 19 q$ codeletion is thought to be a mechanism to inactivate CIC and FUBP1 (Fig. 1). Across three studies [12, 89, 90], of 80 oligodendrogliomas (OII) and 89 anaplastic oligodendrogliomas (OIII) $39 \%$ of OII and $51 \%$ OIII had a CIC mutation. In two studies [12, 89] $14 \%$ OII (36 analysed) and 25\% OIII (49 analysed) had a FUBP1 mutation. Of these, 9 tumours had a mutation on both genes $[12,89]$. To implement mutational analysis into diagnostic practice in neuropathology diagnostics, Baumgarten et al [91] correlated loss of FUBP1 immunoreactivity with the mutation status and found a $100 \%$ sensitivity and $90 \%$ specificity, i.e. all immunonegative tests had a mutation and IHC would miss $10 \%$ of mutations detected by sequencing.

The Far Upstream Element [FUSE] Binding Protein 1 (FUBP1) regulates cell cycle regulators MYC and p21 [92, 93]. FUBP1 binds to single-stranded DNA, in particular the far upstream element (FUSE) of the oncogene MYC [94]. Whilst overexpression of FUBP1 can stimulate MYC expression [94], later studies also suggest that FUBP1 forms part of a complex with the FUBP1 interacting repressor (FIR, a.k.a. PUF60) that negatively regulates MYC expression [93]. The recent finding of inactivating mutations of FUBP1 in the context of oligodendroglioma are in line with the notion that FUBP1 mutations lead to MYC activation 
by relieving the suppressing effects of the complex formed by FUBP1, FUBP1 interacting repressor (FIR) and FUSE [93].

The protein encoded by capicua, $\mathrm{CIC}$ is a downstream component of receptor tyrosine kinase (RTK) pathways including EGFR, Ras, Raf, and MAP kinases [95]. RTK signalling, (e.g. EGFR) blocks the function of $\mathrm{CIC}$ thus activating targets that are usually repressed by it. 8 of 11 [89], 7 of 10 [12] and 14 of 15 [90] missense mutations observed in oligodendroglial tumours are located in the highly conserved HMG box functional domain of the $\mathrm{CIC}$ protein.

Immunohistochemical detection of nuclear $\mathrm{ClC}$ is absent in $\mathrm{CIC}$ mutant tumours [96], although the correlation between DNA mutation and loss of protein expression has not been validated in this study.

In conclusion, $C I C$ and FUBP mutation analysis, specifically when the immunohistochemical tests are available, in combination with ATRX immunostaining, may prove as useful additional markers that can help classify astrocytic and oligodendroglial tumours ahead of a $1 p / 19 q$ test, and can be helpful in those settings where the availability of $1 p / 19 q$ tests is limited or associated with delays. A prognostic value for CIC and FUBP1 has yet to be determined.

\section{TERT mutations}

Summary: Telomerase reverse transcriptase (TERT) is essential in maintaining telomere length and its activity is pathologically increased in a number of human cancers, including GBM. TERT and IDH mutations are mutually exclusive in GBM, but co-occur in oligodendrogliomas (Fig. 4). Two large studies show conflicting results with regard to TERT mutation status and survival, but it is possible that TERT may in the future become a useful prognostic marker.

Prognostic and predictive value: In a large study comprising more than 400 GBM, astrocytomas and oligodendrogliomas, TERT promoter mutations were seen in $74 \%$ of GBM, but only in a minority of Grade II-III astrocytomas (18\%) [97]. This and other studies [41, 98] also show that TERT and IDH mutations are largely mutually exclusive in GBM and astrocytomas, but co-occur in most oligodendrogliomas (Fig. 4). In the study by Killela et al [97] Patients with TERT promoter mutations alone (i.e. no IDH mutation) had the poorest OS (median 11.3 months), patients with tumours without TERT or IDH1/2 mutations had a slightly better survival (median 16.6 months), whilst patients with IDH-only mutant GBM had the best survival (median 42.3 months). Although an earlier study with 358 patients found no significant difference in overall survival between TERT mutant and TERT wild-type (IDH wt) GBM [98], the role of TERT mutations may in the future provide a tool to identify nonIDH1/2 mutant GBMs and suggests that combined IDH1/2 and TERT promoter genotyping will be useful for patient management.

Diagnostic value: Knowledge of the TERT promoter status in tumours is likely to become of growing interest for molecular classification and as a potential target for therapy. Analysis of TERT promoter mutations in 1,515 CNS tumours showed 327 mutations, predominantly in adult patients, with a strong association with older age $(p<0.0001)$ [99]. Mutations were seen in gliosarcomas ( $81 \%)$, oligodendrogliomas (78\%), oligoastrocytomas (58\%), and 
primary GBMs (54 \%). TERT promoter mutations are also strongly associated with $1 \mathrm{p} / 19 \mathrm{q}$ codeletion $(p<0.0001)$, and inversely associated with loss of ATRX expression $(p<0.0001)$ and IDH1/IDH2 mutations ( $<$ 0.0001) [41, 99] (Fig. 4).

Molecular Mechanisms: The enzyme telomerase reverse transcriptase (TERT), part of the telomerase protein complex plays a critical role in extending the telomeres, repetitive nucleotide sequences at the ends of chromosomes. Telomere length shortens with each cell division, ultimately leading to replicative senescence. Thus, the ability to maintain telomere length is a feature of neoplasia. Mutations in the TERT promoter, resulting in overexpression of $T E R T$ is a feature of most human cancers including gliomas [41, 97, 99, 100]. It has been suggested that tumours derived from cell populations with low self-renewal capacity generally rely on alterations that restore telomerase activity, while epigenetic mechanisms maintain telomerase activity in tumour types derived from self-renewing stem cells [101]. Intriguingly, ATRX or DAXX mutations have been shown to underlie a telomere maintenance mechanism not involving telomerase ("alternative lengthening of telomeres"; ALT) the mechanisms responsible for telomerase activity in cancers. Killela et al [101] suggest two options to maintain telomere lengths as cells divide: through epigenetic regulation of telomerase activity, in stem cells of tissues that are rapidly renewing, and (in pathological context) through somatic mutations that maintain telomere lengths, such as mutations in the TERT promoter or mutations in DAXX or ATRX.

\section{Histone H3 mutations}

Summary: Initially detected in paediatric malignant brain stem glioma, $\mathrm{H} 3$ histone family $3 \mathrm{~A}$ (H3F3A) mutations also occur in adult GBM and in locations other than brain stem. The frequency has not yet been established but an estimate by the authors ranges around $5 \%$ of all adult GBM harbouring this alteration (Fig. 4). Similar to paediatric GBM, H3F3A mutations in adult patients frequently co-occur with ATRX mutations (Fig. 3B, Fig. 4). These patients rarely exhibit gain of $7 p$, and usually carry $10 q$ loss. EGFR amplification usually does not occur in this group. The average patient age at manifestation is significantly younger than that of typical GBM patients.

\section{Other frequent alterations in glioblastomas}

A recent study of more than 400 gliomas with Illumina $450 \mathrm{k}$ CpG island methylation arrays showed that combined $10 q$ loss and $7 p$ gain are a feature of $60 \%(81 / 136)$ primary, IDH wildtype GBM (Fig. 4) and nearly all gliosarcomas (93\%, 13/14) [41] (Fig. 2 B, C). EGFR amplification is a feature of $28 \%(38 / 136)$ of primary IDH wild-type GBM, most of which also have $7 p$ gains and $10 q$ loss (Fig. 4).

\section{Mutations in the BRAF gene and the MAP kinase pathway}

Summary: $B R A F$ gene mutations activate the MAP kinase pathways and stimulate growth. Point mutations of the BRAF gene (resulting in the BRAF protein V600E mutation) are present in a range of low grade glial and glioneuronal tumours, such as pleomorphic xanthoastrocytomas (PXA), gangliogliomas, subependymal giant cell astrocytomas (SEGA), desmoplastic infantile gliomas and pilocytic astrocytomas. BRAF gene rearrangements and generation of a fusion gene product are signature mutations in pilocytic astrocytomas. 
Whilst diagnostically useful, in particular to discriminate from diffuse astrocytomas, they are not prognostically relevant.

\section{BRAF V600E point mutation:}

Summary: Unlike the discovery of $I D H$ mutations through deep sequencing [49], the discovery of the BRAF V600E mutation in a sizeable proportion of gangliogliomas, PXA and in a small number of anaplastic PXA/giant cell GBM was made through a conventional and hypothesis-driven approach, following the previous discovery of the BRAF point mutation to be present in $7-15 \%$ of human cancers, including melanoma, colon and ovarian cancer [102]. Using a PCR multiplexing tumour genotyping assay, tumour specimens tested prospectively guided clinical decision making toward targeted therapies [103]. A similar study, conducted at the same time, looked into the presence of the BRAF V600E mutation in a wider range of intrinsic glial and glioneuronal tumours and found the BRAF V600E mutation in addition to PXA and anaplastic PXA also in gangliogliomas and anaplastic gangliogliomas [104]. More recently the BRAF V600E mutation was detected in papillary craniopharyngiomas [105], in contrast to activating mutations of the 8 -catenin gene (CTNNB1) in adamantinomatous craniopharyngiomas. In specific instances the detection of the BRAF V600E mutation can help discriminating craniopharyngiomas from Rathke cleft cysts with unusual presentations [106].

Prognostic and predictive value: A wide spectrum of low grade glial and glioneuronal tumours, many clinically presenting with long-standing epilepsy in children and adults have been identified as BRAF V600E mutant. The mutation is most commonly seen in PXA and the anaplastic form of PXA (65\%) [107, 108], followed by gangliogliomas $(25 \%)[104,109,110]$ and DNT (30\%) [109], and it is occasionally seen in desmoplastic infantile ganglioglioma/astrocytoma (16\%) [111, 112] and pilocytic astrocytomas (10\%) [104, 109 , 113]. Small series of cases of GBMs with giant cell components and morphological variants thereof were reported [114-117]. The prognostic value of the BRAF V600E mutation is less well established than that of $I D H$ mutations in astrocytomas and oligodendrogliomas. This may be attributed to the overall small number and the less well established survival data of the significantly more diverse group of tumours with the BRAF V600E mutation. Case series of gangliogliomas suggest a slightly worse survival of BRAF V600E mutant tumours [118].

Diagnostic value: Unusual forms of temporal astrocytomas, clinically presenting with frequent, sometimes refractory seizures and no other neurologic deficit have been reported with BRAF V600E mutations (Table 1). Many of these tumours had a spindle cell component and were fairly well demarcated [119]. Unlike the multiple IDH1 and IDH2 mutations, which require sequencing $[46,60]$, the detection of the single BRAF V600E mutation is more straightforward. Although the VE1 antibody is fraught with more technical difficulties [120] than the IDH ${ }^{\mathrm{R} 132 \mathrm{H}}$ antibody, it may be superior to the sole use of sequencing, as it can be done as part of the clinical routine and it has been reported to detect the mutation in sequencing-negative cases or in cases where DNA had to be extracted from selected microdissected areas to enrich for mutant cells $[110,111]$. It has been suggested that the use of the antibody may reveal a higher proportion of BRAF V600E mutant gangliogliomas than previously thought [118]. The advantages of immunohistochemistry over sequencing are the wide availability and the rapid turnaround time, enabling a molecular diagnosis on 
the same or next day. More recently, the BRAF V600E mutation has been identified in $94 \%$ of papillary craniopharyngiomas (34/36) [105], while adamantinomatous craniopharyngiomas frequently $96 \%$ (51/53) show CTNNB1 mutations resulting in nuclear localisation of $\beta$-catenin [105]. It has been suggested that the mutual exclusivity of mutations in BRAF and CTNNB1 and the easily available immunohistochemistry for BRAF V600E and nuclear $\beta$-catenin could be used to distinguish papillary from adamantinomatous craniopharyngiomas in morphologically ambiguous cases [106] and may also be used to direct patients to appropriate clinical trials.

Molecular Mechanisms: Cells respond to extracellular signals by transmitting intracellular instructions to coordinate appropriate responses. Highly conserved mitogen-activated protein kinase (MAPK) or extracellular signal regulated protein kinase (ERK) cascades are often used to transduce these signals [121]. These cascades consist of a three-kinase module that includes a MAPK, which is activated by a MAPK/ERK kinase (MEK), which in turn is activated by a MEK kinase (MEKK). The first and best characterized MAPK cascade consists of Raf isoforms, MEK1/2, and ERK1/2, and is regulated by Ras (Fig. 5). The RAS-RAF-MEK-ERK pathway mediates cell responses to growth signals, and regulates cell proliferation, survival, and senescence in response to extracellular signals [121]. RAS is a small G protein that is attached to the inner surface of the plasma membrane, whereas RAF, MEK, and ERK are cytoplasmic protein kinases that consecutively activate each other, forming a three-tiered signalling cascade. There are three RAF isoforms in mammals, A-RAF, B-RAF, and C-RAF. The three $R A F$ genes code for cytoplasmic serine/threonine kinases that are regulated by binding RAS [122]. RAS is mutated to an oncogenic form in about $15 \%$ of human cancer. All $B-R A F$ (BRAF) mutations occur within in the kinase domain of the BRAF protein. The most common mutation in BRAF is a glutamic acid for valine substitution at position 600 (V600E, previously V599E) [102].The mutation is phospho-mimetic, resulting in an activated protein that signals to MEK-ERK constitutively, stimulating cell proliferation and survival (Fig. 5).

\section{BRAF Fusion gene mutations}

Summary: A different type of mutation involving the BRAF gene is found predominantly in pilocytic astrocytomas (PA). The mutation is associated with a gain at the locus $7 q 34$. The tandem duplication produces a fusion gene of the genes KIAA1549 and the BRAF gene. The most common fusion is between KIAA1549 exon 16 and BRAF exon 9 (KEx16BEx9; 20 cases) followed by KIAA1549: BRAF 15-9 and KIAA1549:BRAF 16-11 [123, 124]. Very rare mutations are KIAA1549-BRAF 18-10 and KIAA1549:BRAF 19-9 [124].

Prognostic and predictive value: So far, no differences in survival between tumours with and without BRAF duplication/fusion have been found $[123,125,126]$. However despite this prognostically uninformative molecular signature, a beneficial result from these findings could be the possibility to develop targeted treatment options. Inhibitors of the MAPK pathway, such as AZD6244 and Sorafenib, have been developed and approved for the treatment of several other cancers and may be useful for the treatment of children with tumours that are difficult to resect or are aggressive [124]. Somatic duplication of $7 q 34$ is specific to pilocytic astrocytomas. The frequency of the mutation varies with the tumour location, cerebellar being most frequent (80\%) followed by brainstem and optic pathway 
tumours ( 60\%), whereas it is rare in hemispheric juvenile PA (10-20\%) [127]. In contrast only $9 \%$ BRAF V600E mutations are seen in adult or paediatric PA [104].

Diagnostic value: With one exception [128] BRAF gene fusions were to date identified only in PA and not in any other types of brain tumours, such as diffuse astrocytoma and oligodendroglial tumours, GBM, ependymoma, medulloblastoma, atypical teratoid/rhabdoid tumour (AT/RT), choroid plexus papilloma and -carcinoma, dysembryoplastic neuroepithelial tumour, ganglioglioma, or papillary glioneuronal tumour [129]. PCR-based methods such as fusion detection in genomic DNA [130] or in CDNA [123] and tissue based methods such as FISH (fluorescence in situ hybridization) [64] can be used to detect the fusion product. The combination of BRAF fusion tests and $I D H$ mutation analysis can be diagnostically useful in low grade astrocytomas lacking characterising morphological hallmarks.

Molecular mechanisms: In each fusion protein the N-terminus of RAF is replaced by that of KIAA1549. The $\mathrm{N}$-terminal autoinhibitory domain of BRAF is lost whilst the C-terminal kinase domain is retained, resulting in a constitutive kinase activity of the $B R A F$ fusion gene product [124]. It is thought that the gene fusions arise from tandem duplication events [125, 126, 131]. Two mechanisms are implicated in the creation of tandem duplications in cancers, non-allelic homologous recombination and non-homologous end joining [132], of which the former is the more likely mechanism in the BRAF fusion generation in pilocytic astrocytomas [125].

\section{The role of MAP kinase activation in the pathogenesis of pilocytic astrocytomas}

Pilocytic astrocytomas occur in infra and supratentorial compartments in children and adults. The role of BRAF gene fusions [123-127]; and to a lesser extent, BRAF V600E point mutations [104] and NF2 mutations [133] is well established. A recent study [134] has added significant new information about genes other than BRAF, that activate the MAPK pathway. Whole-genome sequencing with matched RNA sequencing discovered 4 new BRAF fusions, all resulting in loss of the N-terminal regulatory region of BRAF (RNF130-BRAF fusion, RUFY1 (encoding RUN and FYVE domain-containing 1 ) and TMEM178B (encoding transmembrane protein 178B).

Other mutations occurred in KRAS. 19\% of the non-cerebellar tumours showed two new gene fusions involving the region encoding the kinase domain of TrkB. The downstream effects of TrkB activation are mediated, at least in part, via MAPK pathway activation. A new mutation was found in the kinase domain of FGFR1 and in in the phosphatase gene PTPN11 (SHP-2) encoding a RAS-MAPK-related adaptor protein.

The study concludes that all pilocytic astrocytomas in their cohort harboured a MAPK pathway alteration; in addition to BRAF also FGFR1, KRAS and NF1. The mutations were almost always single pathway mutations, suggesting that BRAF kinase activation alone is a driver mutation in pilocytic astrocytomas. All FGFR1-mutant tumours were extracerebellar, mostly in midline locations, suggesting a link between cell of origin and/or microenvironment with FGFR1-driven tumourigenesis [134].

\section{The role of the methylation of the MGMT promoter}


Summary: MGMT promoter methylation in GBM is a prognostic and predictive biomarker indicating response to chemoradiation. It has no diagnostic value.

Prognostic and predictive value: MGMT promoter methylation is a prognostic and predictive biomarker [135]. This was demonstrated in the EORTC NCIC registration trial for TMZ in newly diagnosed GBM where patients with MGMT promoter methylated tumours derived most benefit when treated with TMZ [136]. The addition of the integrin antagonist cilengitide to radiation and TMZ chemotherapy in MGMT methylated GBM was initially promising [137], but was not confirmed in a larger clinical trial which did not show a benefit for progression-free or overall survival $[138,139]$. The trial of the effect of TMZ on newly diagnosed GBM $[136,140]$ showed that MGMT promoter methylation was an independent favourable prognostic factor. Patients with tumours with methylated MGMT promoter had a survival benefit when treated with TMZ and radiotherapy, compared to those who received radiotherapy only, whilst absence of $M G M T$ promoter methylation resulted in a smaller and statistically insignificant difference in survival between the treatment groups. Further studies showed that patients with MGMT promoter-unmethylated tumours had no survival benefit from chemotherapy, regardless of whether given at diagnosis together with RT or as a salvage treatment $[141,142]$. Prospective randomized trials, (NOA-08) [26], the Nordic trial [143] and RTOG 0525 [144] concluded that MGMT promoter methylation is a useful predictive biomarker to stratify elderly GBM patients for RT versus alkylating agent chemotherapy. Accordingly, these consistent trial results suggest that elderly GBM patients eligible for either RT or TMZ should undergo MGMT promoter methylation testing prior to clinical decision making.

Diagnostic value: Testing MGMT promoter methylation has currently no diagnostic value. The "MGMT status" can be tested by assessing promoter methylation, mRNA or protein expression or enzymatic activity. Methylation-specific PCR (MSP)-based detection of MGMT promoter methylation has provided robust results as judged by clinical correlations $[78,135$, $145,146]$ and is currently the only prospectively validated test for MGMT promoter methylation assessment in GBM [147]. However an internationally accepted consensus about the most appropriate diagnostic method is still missing. Most methodologies lack published validation according to guidelines for molecular diagnostics. In practice, the choice of method thus preferentially depends upon the individual experience, equipment of each laboratory (eg. availability of a pyrosequencer, real-time PCR machine or a molecular facility to process methylome chips), and the level of validation [80]. Previous attempts to simplify the tests by detecting MGMT protein by imunohistochemistry had failed, in that it showed a poor inter-observer agreement and thus no correlation to molecular test results [146]. Quantitative or semiquanitative methods include methylation-specific pyrosequencing, methylation-specific multiplex ligation-dependent probe amplification (MS-MPLA) [148], methylation-sensitive high-resolution melting (MS-HRM) [149] bead array- mass spectroscopy, and denaturing high-performance liquid chromatography (HPLC) as reviewed in [135]. Whole-genome Illumina beadchips (HM450) can identify the "MGMT status" as part of the cancer methylome $[78,80]$.

Molecular Mechanisms: The O(6)-Methylguanine-DNA Methyl Transferase (MGMT) is a DNA repair enzyme that reverts the naturally occurring mutagenic 06-methylguanine back to guanine. This prevents errors during DNA replication. In the context of chemotherapy with 
alkylating agents (e.g. TMZ) it removes a cytotoxic lesion, thus counteracting the chemotherapeutic effects of the drug. Aberrant, cancer-related methylation of the MGMT promoter region leads to its silencing, a reduction of the MGMT enzyme expression and subsequently to less repair activity of DNA damage, including that induced by TMZ (Fig. 6).

\section{Summary, conclusions and outlook:}

The advances in identifying biomarkers have significantly shaped our perception of the histopathogenesis of brain tumours. The presence of a common mutation in a spectrum of brain tumours, for example IDH mutations in astrocytomas and oligodendrogliomas (Fig. $3,4)$, or of the BRAF V600E mutation in an even wider range of low grade intrinsic tumours (Table 1) has highlighted the need for a redefinition of the classification of brain tumours. However, it reassuringly underlines the importance of the correct histological diagnosis (Fig. 3 ), essential to guide for appropriate molecular tests and subsequent provision of an integrated report and combined tissue and molecular based opinion to guide the neurooncological management of these tumours. Genome wide assays, such as the 450k Illumina beadchips that assays $450.000 \mathrm{CpG}$ islands, or next generation sequencing are now being tested in a few large centres. This may define new (molecularly and histogenetically characterised) brain tumour entities, and at the same time remove morphologically similar but biologically diverse entities. Certainly there will be immense opportunities but also significant challenges to the way we will diagnose brain tumours in the future.

\section{Acknowledgements:}

This work was undertaken at UCLH/UCL who received a proportion of funding from the Department of Health's NIHR Biomedical Research Centre's funding scheme. Research on brain tumours in S.B.'s laboratory is funded by the Brain Tumour Charity (UK) and by the UCL PhD Impact scheme.

\section{Figure legends:}

Figure 1: Chromosomal translocations leading to $1 p / 19 q$ codeletions (based on data from [42]. A, a normal cell contains two copies of chromosomes 1 and 19, each of which has a short ("petit"; p) and long (q) arm. The location of CIC (on 19q13.2) and FUBP1 (on 1p31.10) are indicated, as well as the most commonly used probes on 1p36, 19q13 and controls on $1 q 24$ and 19p13 [43, 150]. B, unbalanced translocation leads to a transposition at centromere level of $19 q$ to $1 p$ (left, shaded) and its subsequent loss, and of the formation of a derivative chromosome consisting of $1 q$ and $1 p$ and, on centromere level, form the "derivative ("der") chromosome der(1;19)(p10;q10), where "p10" and "q10" indicate centromeric location on the chromosome. $C$, the loss of chromosomal arms $1 p$ and $19 q$ results in one copy of $1 p$ and of $19 q$, and two copies of $1 q$ and $19 p$.

Figure 2: Typical copy number profiles of oligodendroglioma and glioblastoma: $A$, classical profile of an oligodendroglioma with $1 p / 19 q$ codeletion. $B$, classical profile of a GBM with $7 p$ gain with EGFR amplification and 10q deletion. C, GBM with segmental loss of $1 p$, and again 
the characteristic $7 p$ gain and $10 q$ deletion. In addition there are also deletions of $10 p$, and 15q. Small segmental deletions on Chr $1 p$ can mislead when using a single FISH or qPCR probe in the $1 p .36$ region [151].

Figure 3: Algorithm for the integrated diagnosis of astrocytomas, oligodendrogliomas and glioblastomas. A, diagnostic pathway for tumours that correspond histologically to oligodendrogliomas or astrocytomas. Following initial assessment on H\&E stained sections, immunostaining for IDH1 R132H and ATRX can positively identify the majority of oligodendrogliomas and astrocytomas (Col 2, 4). It is recommended that IDH1 R132H immunonegative tumours are followed up by sequencing to identify rare IDH1 and all IDH 2 mutations ( $\mathrm{Col} 1,3,5,6)[46,60]$. Testing for $1 \mathrm{p} / 19 q$ codeletions is the next essential step (red outline) to identify oligodendrogliomas (Col. 1, 2a) and discriminate them from a small number of $I D H$ mutant, ATRX retained astrocytomas (Col $2 \mathrm{~b}$, red outline, hatched filling). The group of IDH mutant, ATRX-negative (=mutant) and $1 \mathrm{p} / 19$ non-codeleted tumours corresponds to astrocytomas $(\mathrm{Col} 3,4)$. The remaining groups of $I D H$ wild-type tumours may represent infiltrating GBM, or other tumours ( $\mathrm{Col} 5$ ). A small number of $I D H$ wild-type and ATRX negative (mutant) GBM show mutations in the Histone $\mathrm{H3}$ gene (Col 6). Clinically, patients with $\mathrm{H} 3$ mutant (anaplastic) astrocytomas have a prognosis similar to those with GBM.

B, Diagnostic pathways for tumours with histological appearance of a GBM. All tumours undergo testing with antibodies for mutant IDH1 R132H and ATRX to identify a small number of anaplastic oligodendrogliomas or GBM with IDH mutations (Col 2, 4). Depending on the resources, subsequent sequencing may be added to identify a small proportion of these tumours that carry a rare $I D H$ mutation not detected by immunostaining (Col. 1, 3, 5, 6) [46, 60]). The majority of "IDH mutant GBM" have an ATRX loss $(\mathrm{Col} 3,4)$ whilst a small number of GBM are IDH mutant with ATRX retained ( $\mathrm{Col} 2 \mathrm{~b}$ ). Col 5 represents the most common form of morphological GBM: IDH wild-type, ATRX retained and 1p/19q non-codeleted (retained). A small number of GBM are IDH wild-type, with ATRX loss and Histone mutation (Col 6) and have a similar prognosis as the GBMs as shown in Col 5. This scheme also suggests that the diagnosis of oligoastrocytomas can be phased out, in particular with support of molecular data (See also Fig. 4).

Figure 4: Integrated diagnosis based on molecular data of more than $\mathbf{4 0 0}$ gliomas. The data were obtained from the supplementary material of [41] and were further analysed and colour coded in MS Excel. Primary sorting criterion was the "integrated diagnosis", followed by IDH, 1p/19q, ATRX, TERT and H3 status. All samples were analysed with Illumina 450k methylation arrays as described in [41]. The top row shows the diagnosis according to the WHO 2007 classification of brain tumours, and below the reclassification ("integrated diagnosis") based on histology and combinations of molecular markers, which has now resulted in the elimination of oligoastrocytomas and GBM-O and their reclassification into astrocytomas, oligodendrogliomas, "GBM-IDH" and "primary GBM". Below, age of the patients with a mean age and the mutation profiles of the tumour classes and grades. IDH mutations define astrocytomas, oligodendrogliomas and a small proportion of GBM ("GBMIDH"; 9.3\%, 14/150). Additional 1p/19q codeletions, TERT mutations and retained ATRX 
expression define oligodendrogliomas. ATRX loss, retained $1 p$ and TERT wild-type are a feature of astrocytomas (of which approximately $25 \%$ have a $19 q$ deletion). IDH mutant GBM show $10 q$ loss and no TERT mutations. The majority of IDH wild-type ("primary") GBM show $7 p$ gain, and $10 q$ loss. EGFR amplification is seen in primary GBM only. ATRX mutant GBM are IDH wild type and often have a Histone H3F3 (K27M or G34R) mutation and occur in younger patients within the GBM group. This schematic reflects the changes that are stipulated by the International Society of Neuropathology-Haarlem Consensus Guidelines for Nervous System Tumor Classification [13], in that (i) disease entities should be defined as precisely and objectively as possible in order to establish highly biologically and clinically uniform groups, (ii) some entities will require molecular information to provide an "integrated" diagnosis, (iii) resulting in a "layered" diagnosis. These layers will comprising (a) the integrated diagnosis (top layer), followed by (b) histological classification, (c) WHO grade, and (d) molecular information.

Figure 5: Activating mutation in the MAP kinase (MAPK) pathway and its role in pilocytic astrocytomas pathogenesis $[123,131,134]$ : MAPKs are involved in directing cellular responses to regulate proliferation, gene expression, differentiation, mitosis, cell survival, and apoptosis. Under physiological conditions, the pathway is activated by ligand binding to receptor tyrosine kinases. Here, activating point mutations of FGFR1 (red star) and activating fusion mutations fusions of the TRKB receptor have been identified. Physiological ligand binding and both mutations result in phosphorylation of specific intracellular tyrosine residues and creates binding sites for the adapter proteins (GRB2, GAB1, SOS, and SHP2). Mutations in SHP2 (also known as PTPN11, blue star) have been found in conjunction with FGFR1 mutations but are not thought to be sufficient to induce oncogenic signals themselves [134]. Activation of the adapter proteins result in an activation of Ras which subsequently activates Raf and BRAF. Under pathological conditions, Raf can be activated by mutant KRas or by relief of the inhibitory action of NF1 (inactivating NF1 mutation indicated by yellow star). The BRAF V600E mutation and the BRAF fusions both activate BRAF signalling and act on downstream targets, similar to the physiological action of Raf and BRAF. Both mechanisms activate the downstream cascade of MEK (Mitogen-activated protein kinase kinase) and ERK (extracellular signal-regulated kinases) which trigger intracellular growthstimulating transcription factors. The percentages relate to the frequencies of mutations in juvenile pilocytic astrocytomas [134].

Figure 6: Role of MGMT promoter methylation and response to alkylating agents: Expression of the DNA repair protein 06- methylguanine-methyltransferase (MGMT) results in resistance of tumours to alkylating agents. $A, M G M T$ is a cellular DNA repair protein that re verses alkylation (including methylation) at the $\mathrm{O}^{6}$ position of guanine. $\mathrm{B}$, Methylation of the MGMT promoter is an epigenetic event leading to silencing of the promoter and thus reduced expression of the active enzyme, MGMT. C; High levels of MGMT activity in tumour tissue confer with resistance to alkylating agents (left), whilst methylation of the MGMT promoter result in reduced MGMT repair activity, and this are associated with increased sensitivity to alkylating agents (right). 
Table 1: Meta-Analysis of BRAF V600E mutant case series in intrinsic brain tumours in the literature (excluding case reports of less than 5 cases)

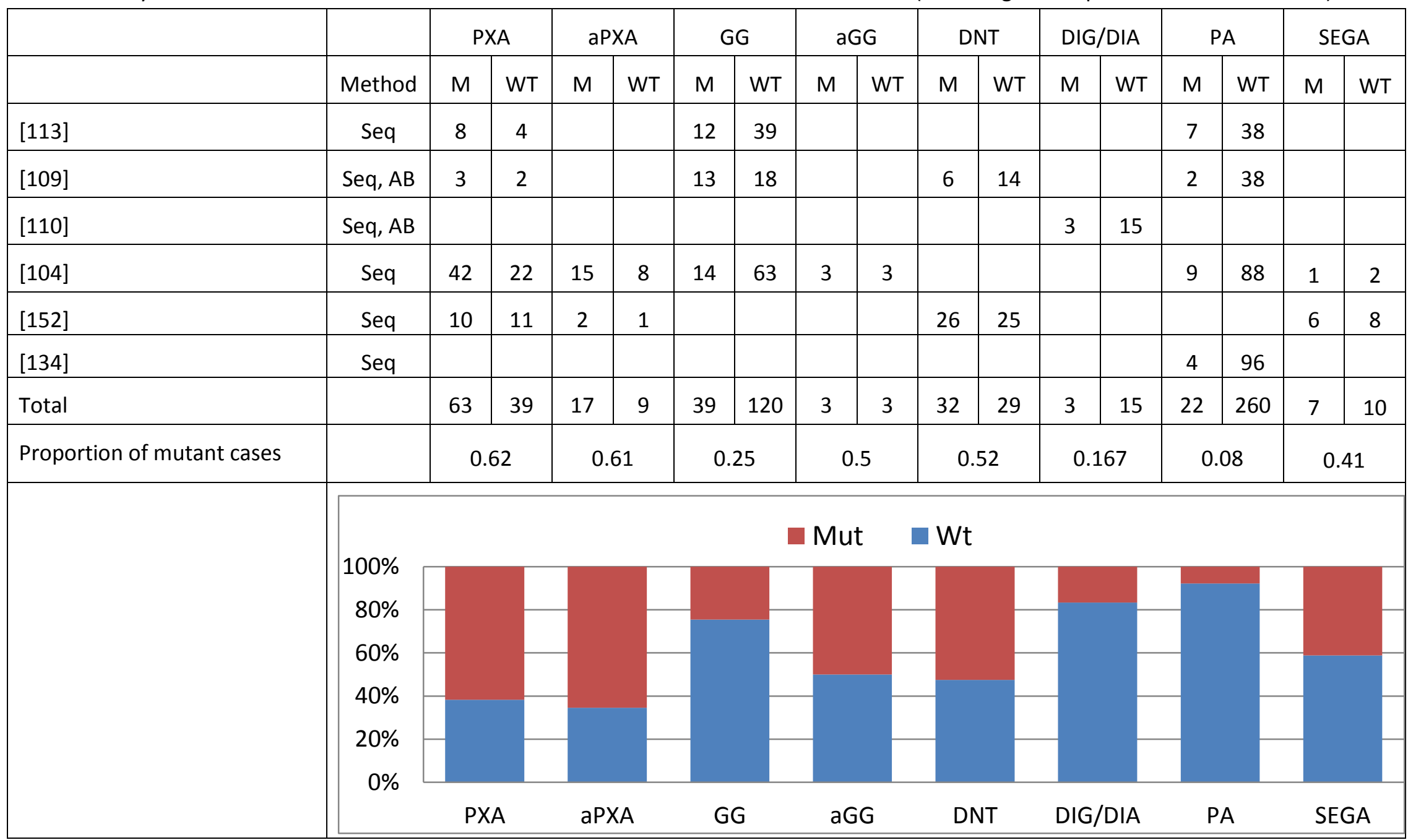

The upper row indicates the abbreviated histological diagnosis: PXA and aPXA, (anaplastic) pleomorphic xanthoastrocytoma; GG and aGG, (anaplastic) gangliogliomas; DNT, dysembryoplastic neuroepithelial tumour; DIG/DIA, desmoplastic infantile ganglioglioma/ astrocytoma; PA, pilocytic astrocytoma. Second row and second column: Method of the detection of the mutation: seq, sequencing; $A B$, antibody; Second row: M, mutant; WT, wild-type or nonmutant. The penultimate row indicates the cumulative number of mutant or wild-type cases in the studies, and the last row indicates the proportion of

Page | 17 
mutant cases per diagnostic group. The inset graph illustrates the proportion of mutant and non-mutant (wt) tumours for each entity, based on the numbers in the table above. 
Table 2: Overview of diagnostically and prognostically relevant molecular tests. Abbreviations: DA diffuse astrocytoma; AA anaplastic astrocytoma; DNT dysembryoplastic neuroepithelial tumour; DIPG (paediatric) diffuse intrinsic pontine glioma, non-BS DIPG non brain stem DIPG; OD oligodendroglioma; OA, oligoastrocytoma; DIA, desmoplastic infantile astrocytoma; HG, high grade; LG low grade; PXA, pleomorphic xanthoastrocytoma.

\begin{tabular}{|c|c|c|c|c|c|c|c|c|c|}
\hline $\begin{array}{l}\text { Reference for } \\
\text { application in } \\
\text { Neuropathology }\end{array}$ & $\begin{array}{l}\text { Molecular } \\
\text { marker or } \\
\text { target }\end{array}$ & $\begin{array}{l}\text { Type of } \\
\text { mutation }\end{array}$ & $\begin{array}{l}\text { Relevant to confirm } \\
\text { which brain tumours }\end{array}$ & $\begin{array}{l}\text { Positive test } \\
\text { excludes DD }\end{array}$ & Frequency & $\begin{array}{l}\text { Correlation } \\
\text { with other } \\
\text { markers }\end{array}$ & $\begin{array}{l}\text { Diagnostically } \\
\text { relevant }\end{array}$ & $\begin{array}{l}\text { Prognostically } \\
\text { relevant }\end{array}$ & Test method \\
\hline$[37,38]$ & Chr 1p/19q & Codeletion & Oligodendroglioma & $\begin{array}{l}\text { Diffuse } \\
\text { astrocytomas, } \\
\text { neurocytomas, DNT }\end{array}$ & $>80 \%$ in $\mathrm{OD}$ & $\begin{array}{l}\text { Co-segregates } \\
\text { with } I D H \\
\text { mutations }\end{array}$ & Yes & Yes & $\begin{array}{l}\text { qPCR } \\
\text { FISH }\end{array}$ \\
\hline$[9,10,58]$ & $I D H 1, I D H 2$ & $\begin{array}{l}\text { Point } \\
\text { mutation }\end{array}$ & $\begin{array}{l}\text { Astrocytomas, } \\
\text { Oligoastrocytomas, } \\
\text { Oligodendrogliomas }\end{array}$ & $\begin{array}{l}\text { Pilocytic } \\
\text { astrocytomas }\end{array}$ & $70-85 \%$ & $\begin{array}{l}I D H 1 \text { and } I D H 2 \\
\text { are mutually } \\
\text { exclusive }\end{array}$ & Yes & Yes & $\begin{array}{l}\text { Mutation } \\
\text { specific IHC } \\
\text { Sequencing } \\
\text { for IHC neg }\end{array}$ \\
\hline$[39,41]$ & ATRX & $\begin{array}{l}\text { Mutation, } \\
\text { deletion }\end{array}$ & $\begin{array}{l}\text { Diffuse and anaplastic } \\
\text { astrocytoma }\end{array}$ & Oligoastrocytomas & $\begin{array}{l}50 \%-90 \text { of } \\
\text { DA and AA }\end{array}$ & $\begin{array}{l}\text { Largely } \\
\text { mutually } \\
\text { exclusive with } \\
1 p / 19 q \\
\text { Mainly in } I D H \\
\text { mut gliomas }\end{array}$ & Yes & Yes & $\begin{array}{l}\text { IHC to } \\
\text { detect loss } \\
\text { (80-90\% } \\
\text { sensitivity) }\end{array}$ \\
\hline [96] & $\mathrm{CIC}$ & Mutations & $\begin{array}{l}\text { Oligodendrogliomas } \\
\text { (Located on 19q) }\end{array}$ & Astrocytomas & $\begin{array}{l}50 \% \text { of } O D \\
\text { with } 1 p / 19 q \\
\text { codeletion }\end{array}$ & $\begin{array}{l}\text { Seen in a subset } \\
\text { of } 1 p / 19 q \\
\text { codeletion }\end{array}$ & Yes & $\begin{array}{l}\text { Limited } \\
\text { (marker for } \\
19 q \text { loss). Best } \\
\text { in combination } \\
\text { with } 1 p \text { test }\end{array}$ & $\begin{array}{l}\text { IHC (loss of } \\
\text { staining) } \\
\text { (sensitivity } \\
\text { not } \\
\text { validated) }\end{array}$ \\
\hline [91] & FUBP1 & Mutations & $\begin{array}{l}\text { Oligodendrogliomas } \\
\text { (Located on } 1 p \text { ) }\end{array}$ & Astrocytomas & $\begin{array}{l}14 \% \text { LG OD, } \\
25 \% \text { HG OD }\end{array}$ & $\begin{array}{l}\text { Seen in a subset } \\
\text { of } 1 p / 19 q \\
\text { codeletion }\end{array}$ & Yes & $\begin{array}{l}\text { Yes (marker } \\
\text { for } 1 p \text { loss) }\end{array}$ & $\begin{array}{l}\text { IHC (loss of } \\
\text { staining) } \\
\text { (sensitivity } \\
90 \% \text { ) }\end{array}$ \\
\hline
\end{tabular}




\begin{tabular}{|c|c|c|c|c|c|c|c|c|c|}
\hline $\begin{array}{l}\text { Reference for } \\
\text { application in } \\
\text { Neuropathology }\end{array}$ & $\begin{array}{l}\text { Molecular } \\
\text { marker or } \\
\text { target }\end{array}$ & $\begin{array}{l}\text { Type of } \\
\text { mutation }\end{array}$ & $\begin{array}{l}\text { Relevant to confirm } \\
\text { which brain tumours }\end{array}$ & $\begin{array}{l}\text { Positive test } \\
\text { excludes DD }\end{array}$ & Frequency & $\begin{array}{l}\text { Correlation } \\
\text { with other } \\
\text { markers }\end{array}$ & $\begin{array}{l}\text { Diagnostically } \\
\text { relevant }\end{array}$ & $\begin{array}{l}\text { Prognostically } \\
\text { relevant }\end{array}$ & Test method \\
\hline $\begin{array}{l}{[104,109,110]} \\
{[120]}\end{array}$ & BRAF V600E & $\begin{array}{l}\text { Point } \\
\text { mutation }\end{array}$ & $\begin{array}{l}\text { PXA } \\
\text { Ganglioglioma } \\
\text { DIA } \\
\text { Pilocytic astrocytoma }\end{array}$ & Diffuse astrocytomas & $\begin{array}{l}\text { PXA:60-70\% } \\
\text { GG: } 25 \% \\
\text { DIA/DIG: } \\
20 \% \\
\text { PA } 5 \%\end{array}$ & $\begin{array}{l}\text { Mutually } \\
\text { exclusive with } \\
\text { BRAF Fusion }\end{array}$ & \multirow[t]{2}{*}{ Yes } & No & \multirow[t]{3}{*}{$\begin{array}{l}\text { Mutation } \\
\text { specific IHC, } \\
\text { Seq }\end{array}$} \\
\hline [105] & & & $\begin{array}{l}\text { Papillary } \\
\text { craniopharyngioma, }\end{array}$ & $\begin{array}{l}\text { Adamantinomatous } \\
\text { craniopharyngioma }\end{array}$ & PC: $94 \%$ & $\begin{array}{l}\text { Mutually } \\
\text { exclusive with } \\
\text { CTNNB } \\
\text { mutation }\end{array}$ & & $\begin{array}{l}\text { To be } \\
\text { confirmed }\end{array}$ & \\
\hline [102] & & & Melanoma & $\mathrm{n} / \mathrm{a}$ & $66 \%$ & & No & $\begin{array}{l}\text { May influence } \\
\text { treatment }\end{array}$ & \\
\hline [153] & BRAF Fusion & $\begin{array}{l}\text { Fusion } \\
\text { transcript }\end{array}$ & Pilocytic astrocytoma & PXA, other LGG & $\begin{array}{l}\text { Depends on } \\
\text { age and } \\
\text { localisation. }\end{array}$ & $\begin{array}{l}\text { Mutually } \\
\text { exclusive with } \\
\text { V600E mutation } \\
\end{array}$ & Yes & No & $\begin{array}{l}\text { RT-PCR Seq } \\
\text { FISH }\end{array}$ \\
\hline$[15,41,154]$ & Histone $\mathrm{H} 3$ & $\begin{array}{l}\text { Point } \\
\text { mutation }\end{array}$ & $\begin{array}{l}\text { non BS-DIPG, } \\
\text { DIPG }\end{array}$ & Not established & $\begin{array}{l}36 \% \text { non BS- } \\
\text { DIPG, } \\
78 \% \text { DIPG } \\
3-5 \% \text { adult } \\
\text { GBM }\end{array}$ & & DIPG & Yes (DIPG) & Seq, IHC \\
\hline$[41,97,98]$ & TERT & $\begin{array}{l}\text { Promoter } \\
\text { mutation }\end{array}$ & & $\begin{array}{l}\text { ATRX mutant } \\
\text { astrocytomas }\end{array}$ & $\begin{array}{l}50-74 \% \text { of } \\
\text { GBM } \\
68 \% \text { OD }\end{array}$ & $\begin{array}{l}\text { Mutually } \\
\text { exclusive with } \\
\text { ATRX loss }\end{array}$ & Yes & $\begin{array}{l}\text { Contradictory } \\
\text { reports }\end{array}$ & Sequencing \\
\hline [155] & MGMT & $\begin{array}{l}\text { Promoter } \\
\text { methylation }\end{array}$ & Non-diagnostic & & $\mathrm{n} / \mathrm{a}$ & $\begin{array}{l}\text { Preference in } \\
I D H \text { mutant } \\
\text { tumours }\end{array}$ & no & Yes, in GBM & $\mathrm{msPCR}$ \\
\hline
\end{tabular}

Page | 20 


\section{Supplementary Material:}

Supplementary table: Data format of Figure 4: Data were obtained from the supplementary material of [41] and further analysed and colour coded in MS Excel. Primary sorting criterion was the "integrated diagnosis", followed by IDH, 1p/19q, ATRX, TERT and H3 status. All colour coding and sample sorting as described in figure 4.

Supplementary figure: Data as shown in Figure 4, formatted as A3, high resolution printout. 


\section{References}

1 Louis DN, Ohgaki H, Wiestler OD, Burger PC, Cavenee WK. WHO Grading of tumours of the central nervous system. In WHO Classification of Tumours of the Central Nervous System Eds. DN Louis, H Ohgaki, OD Wiestler, WK Cavenee, 4th edn. Lyon: WHO Press. 2007 2 Louis DN, Ohgaki H, Wiestler OD, Cavenee WK. Astrocytic Tumours. In WHO Classification of Tumours of the Central Nervous System Eds. DN Louis, H Ohgaki, OD Wiestler, WK Cavenee, 4th edn. Lyon: WHO Press. 2007

3 Bello MJ, Vaquero J, de Campos JM, Kusak ME, Sarasa JL, Saez-Castresana J, Pestana A, Rey JA. Molecular analysis of chromosome 1 abnormalities in human gliomas reveals frequent loss of $1 p$ in oligodendroglial tumors. Int J Cancer 1994; 57: 172-5

4 Reifenberger J, Reifenberger G, Liu L, James CD, Wechsler W, Collins VP. Molecular genetic analysis of oligodendroglial tumors shows preferential allelic deletions on $19 q$ and 1p. Am J Pathol 1994; 145: 1175-90

5 Kraus JA, Koopmann J, Kaskel P, Maintz D, Brandner S, Schramm J, Louis DN, Wiestler OD, von Deimling A. Shared allelic losses on chromosomes 1p and 19q suggest a common origin of oligodendroglioma and oligoastrocytoma. J Neuropathol Exp Neurol 1995; 54: $91-5$

6 Cairncross JG, Ueki K, Zlatescu MC, Lisle DK, Finkelstein DM, Hammond RR, Silver JS, Stark PC, Macdonald DR, Ino Y, Ramsay DA, Louis DN. Specific genetic predictors of chemotherapeutic response and survival in patients with anaplastic oligodendrogliomas. J Natl Cancer Inst 1998; 90: 1473-9

7 Ino Y, Zlatescu MC, Sasaki H, Macdonald DR, Stemmer-Rachamimov AO, Jhung S, Ramsay DA, von Deimling A, Louis DN, Cairncross JG. Long survival and therapeutic responses in patients with histologically disparate high-grade gliomas demonstrating chromosome 1p loss. J Neurosurg 2000; 92: 983-90

8 Jenkins RB, Curran W, Scott CB, Cairncross G. Pilot evaluation of 1p and 19q deletions in anaplastic oligodendrogliomas collected by a national cooperative cancer treatment group. Am J Clin Oncol 2001; 24: 506-8

9 Capper D, Reuss D, Schittenhelm J, Hartmann C, Bremer J, Sahm F, Harter PN, Jeibmann A, von Deimling A. Mutation-specific IDH1 antibody differentiates oligodendrogliomas and oligoastrocytomas from other brain tumors with oligodendroglioma-like morphology. Acta Neuropathol 2011; 121: 241-52

10 Capper D, Weissert S, Balss J, Habel A, Meyer J, Jager D, Ackermann U, Tessmer C, Korshunov A, Zentgraf $\mathrm{H}$, Hartmann C, von Deimling A. Characterization of R132H mutationspecific IDH1 antibody binding in brain tumors. Brain Pathol 2010; 20: 245-54

11 Sahm F, Koelsche C, Meyer J, Pusch S, Lindenberg K, Mueller W, Herold-Mende C, von Deimling A, Hartmann C. CIC and FUBP1 mutations in oligodendrogliomas, oligoastrocytomas and astrocytomas. Acta Neuropathol 2012; 123: 853-60

12 Jiao Y, Killela PJ, Reitman ZJ, Rasheed AB, Heaphy CM, de Wilde RF, Rodriguez FJ, Rosemberg S, Oba-Shinjo SM, Nagahashi Marie SK, Bettegowda C, Agrawal N, Lipp E, Pirozzi C, Lopez G, He Y, Friedman H, Friedman AH, Riggins GJ, Holdhoff M, Burger P, McLendon R, Bigner DD, Vogelstein B, Meeker AK, Kinzler KW, Papadopoulos N, Diaz LA, Yan H. Frequent ATRX, CIC, FUBP1 and IDH1 mutations refine the classification of malignant gliomas.

Oncotarget 2012; 3: 709-22

13 Louis DN, Perry A, Burger P, Ellison DW, Reifenberger G, von Deimling A, Aldape K, Brat D, Collins VP, Eberhart C, Figarella-Branger D, Fuller GN, Giangaspero F, Giannini C, Hawkins C, Kleihues P, Korshunov A, Kros JM, Beatriz Lopes M, Ng HK, Ohgaki H, Paulus W, Pietsch T, Rosenblum M, Rushing E, Soylemezoglu F, Wiestler O, Wesseling P. International 
Society Of Neuropathology--Haarlem consensus guidelines for nervous system tumor classification and grading. Brain Pathol 2014; 24: 429-35

14 Llaguno SRA, Chen YT, McKay RM, Parada LF. Stem Cells in Brain Tumor

Development. In Cancer and Development. 2011: 15-44

15 Schwartzentruber J, Korshunov A, Liu XY, Jones DT, Pfaff E, Jacob K, Sturm D, Fontebasso AM, Quang DA, Tonjes M, Hovestadt V, Albrecht S, Kool M, Nantel A, Konermann C, Lindroth A, Jager N, Rausch T, Ryzhova M, Korbel JO, Hielscher T, Hauser P, Garami M, Klekner A, Bognar L, Ebinger M, Schuhmann MU, Scheurlen W, Pekrun A, Fruhwald MC, Roggendorf W, Kramm C, Durken M, Atkinson J, Lepage P, Montpetit A, Zakrzewska $M$, Zakrzewski K, Liberski PP, Dong Z, Siegel P, Kulozik AE, Zapatka M, Guha A, Malkin D, Felsberg J, Reifenberger $G$, von Deimling A, Ichimura K, Collins VP, Witt $H$, Milde T, Witt O, Zhang $C$, Castelo-Branco P, Lichter P, Faury D, Tabori U, Plass C, Majewski J, Pfister SM, Jabado N. Driver mutations in histone $\mathrm{H} 3.3$ and chromatin remodelling genes in paediatric glioblastoma. Nature 2012; 482: 226-31

16 Chen J, Li Y, Yu TS, McKay RM, Burns DK, Kernie SG, Parada LF. A restricted cell population propagates glioblastoma growth after chemotherapy. Nature 2012; 488: 522-6 17 Henriquez NV, Forshew T, Tatevossian R, Ellis M, Richard-Loendt A, Rogers HA, Jacques TS, Garcia Reitboeck P, Pearce K, Sheer D, Grundy RG, Brandner S. Comparative expression analysis reveals lineage relationships between human and murine gliomas and a dominance of glial signatures during tumour propagation in vitro. Cancer Res 2013:

18 Jacques TS, Swales A, Brzozowski MJ, Henriquez NV, Linehan JM, Mirzadeh Z, O'Malley C, Naumann H, Alvarez-Buylla A, Brandner S. Combinations of genetic mutations in the adult neural stem cell compartment determine brain tumour phenotypes. EMBO J 2010; 29: 222-35

19 Sahm F, Reuss D, Koelsche C, Capper D, Schittenhelm J, Heim S, Jones DT, Pfister SM, Herold-Mende C, Wick W, Mueller W, Hartmann C, Paulus W, von Deimling A. Farewell to oligoastrocytoma: in situ molecular genetics favor classification as either oligodendroglioma or astrocytoma. Acta Neuropathol 2014; 128: 551-9

20 Hainfellner J, Louis DN, Perry A, Wesseling P. Letter in Response to David N. Louis et al, International Society of Neuropathology-Haarlem Consensus Guidelines for Nervous System Tumor Classification and Grading, Brain Pathology, doi: 10.1111/bpa.12171. Brain Pathol 2014; 24: 671-2

21 Zada G, Bond AE, Wang YP, Giannotta SL, Deapen D. Incidence trends in the anatomic location of primary malignant brain tumors in the United States: 1992-2006. World Neurosurg 2012; 77: 518-24

22 Ohgaki $\mathrm{H}$, Kleihues $\mathrm{P}$. Population-based studies on incidence, survival rates, and genetic alterations in astrocytic and oligodendroglial gliomas. J Neuropathol Exp Neurol 2005; 64: 479-89

23 Ohgaki H, Kleihues P. Epidemiology and etiology of gliomas. Acta Neuropathol 2005; 109: 93-108

24 Okamoto Y, Di Patre PL, Burkhard C, Horstmann S, Jourde B, Fahey M, Schuler D, Probst-Hensch NM, Yasargil MG, Yonekawa Y, Lutolf UM, Kleihues P, Ohgaki H. Populationbased study on incidence, survival rates, and genetic alterations of low-grade diffuse astrocytomas and oligodendrogliomas. Acta Neuropathol 2004; 108: 49-56 25 Kouwenhoven MC, Kros JM, French PJ, Biemond-ter Stege EM, Graveland WJ, Taphoorn MJ, Brandes AA, van den Bent MJ. 1p/19q loss within oligodendroglioma is predictive for response to first line temozolomide but not to salvage treatment. Eur J Cancer 2006; 42: 2499-503

26 Wick W, Hartmann C, Engel C, Stoffels M, Felsberg J, Stockhammer F, Sabel MC, Koeppen S, Ketter R, Meyermann R, Rapp M, Meisner C, Kortmann RD, Pietsch T, Wiestler OD, Ernemann U, Bamberg M, Reifenberger G, von Deimling A, Weller M. NOA-04 
randomized phase III trial of sequential radiochemotherapy of anaplastic glioma with procarbazine, lomustine, and vincristine or temozolomide. J Clin Oncol 2009; 27: 5874-80

27 Kujas M, Lejeune J, Benouaich-Amiel A, Criniere E, Laigle-Donadey F, Marie Y, Mokhtari K, Polivka M, Bernier M, Chretien F, Couvelard A, Capelle L, Duffau H, Cornu P, Broet P, Thillet J, Carpentier AF, Sanson M, Hoang-Xuan K, Delattre JY. Chromosome 1p loss: a favorable prognostic factor in low-grade gliomas. Ann Neurol 2005; 58: 322-6

28 McDonald JM, See SJ, Tremont IW, Colman H, Gilbert MR, Groves M, Burger PC, Louis DN, Giannini C, Fuller G, Passe S, Blair H, Jenkins RB, Yang H, Ledoux A, Aaron J, Tipnis $\mathrm{U}$, Zhang $\mathrm{W}$, Hess $\mathrm{K}$, Aldape $\mathrm{K}$. The prognostic impact of histology and $1 \mathrm{p} / 19 q$ status in anaplastic oligodendroglial tumors. Cancer 2005; 104: 1468-77

29 Giannini C, Burger PC, Berkey BA, Cairncross JG, Jenkins RB, Mehta M, Curran WJ, Aldape K. Anaplastic oligodendroglial tumors: refining the correlation among histopathology, 1p 19q deletion and clinical outcome in Intergroup Radiation Therapy Oncology Group Trial 9402. Brain Pathol 2008; 18: 360-9

30 Iwamoto FM, Nicolardi L, Demopoulos A, Barbashina V, Salazar P, Rosenblum M, Hormigo A. Clinical relevance of $1 p$ and 19q deletion for patients with WHO grade 2 and 3 gliomas. J Neurooncol 2008; 88: 293-8

31 Clark KH, Villano JL, Nikiforova MN, Hamilton RL, Horbinski C. 1p/19q testing has no significance in the workup of glioblastomas. Neuropathol Appl Neurobiol 2013:

32 Abrey LE, Louis DN, Paleologos N, Lassman AB, Raizer JJ, Mason W, Finlay J, MacDonald DR, DeAngelis LM, Cairncross JG. Survey of treatment recommendations for anaplastic oligodendroglioma. Neuro Oncol 2007; 9: 314-8

33 Panageas KS, Iwamoto FM, Cloughesy TF, Aldape KD, Rivera AL, Eichler AF, Louis DN, Paleologos NA, Fisher BJ, Ashby LS, Cairncross JG, Roldan Urgoiti GB, Wen PY, Ligon KL, Schiff D, Robins HI, Rocque BG, Chamberlain MC, Mason WP, Weaver SA, Green RM, Kamar FG, Abrey LE, Deangelis LM, Jhanwar SC, Rosenblum MK, Lassman AB. Initial treatment patterns over time for anaplastic oligodendroglial tumors. Neuro Oncol 2012; 14: 761-7

34 Lassman AB, Iwamoto FM, Cloughesy TF, Aldape KD, Rivera AL, Eichler AF, Louis DN, Paleologos NA, Fisher BJ, Ashby LS, Cairncross JG, Roldan GB, Wen PY, Ligon KL, Schiff D, Robins HI, Rocque BG, Chamberlain MC, Mason WP, Weaver SA, Green RM, Kamar FG, Abrey LE, DeAngelis LM, Jhanwar SC, Rosenblum MK, Panageas KS. International retrospective study of over 1000 adults with anaplastic oligodendroglial tumors. Neuro Oncol 2011; 13: 649-59

35 van den Bent MJ, Brandes AA, Taphoorn MJ, Kros JM, Kouwenhoven MC, Delattre JY, Bernsen HJ, Frenay M, Tijssen CC, Grisold W, Sipos L, Enting RH, French PJ, Dinjens WN, Vecht CJ, Allgeier A, Lacombe D, Gorlia T, Hoang-Xuan K. Adjuvant procarbazine, lomustine, and vincristine chemotherapy in newly diagnosed anaplastic oligodendroglioma: long-term follow-up of EORTC brain tumor group study 26951. J Clin Oncol 2013; 31: 344-50

36 Cairncross G, Wang M, Shaw E, Jenkins R, Brachman D, Buckner J, Fink K, Souhami L, Laperriere N, Curran W, Mehta M. Phase III trial of chemoradiotherapy for anaplastic oligodendroglioma: long-term results of RTOG 9402. J Clin Oncol 2013; 31: 337-43 37 Watanabe T, Nakamura M, Kros JM, Burkhard C, Yonekawa Y, Kleihues P, Ohgaki H. Phenotype versus genotype correlation in oligodendrogliomas and low-grade diffuse astrocytomas. Acta Neuropathol 2002; 103: 267-75

38 Aldape K, Burger PC, Perry A. Clinicopathologic aspects of $1 p / 19 q$ loss and the diagnosis of oligodendroglioma. Arch Pathol Lab Med 2007; 131: 242-51

39 Wiestler B, Capper D, Holland-Letz T, Korshunov A, von Deimling A, Pfister SM, Platten $M$, Weller M, Wick W. ATRX loss refines the classification of anaplastic gliomas and identifies a subgroup of IDH mutant astrocytic tumors with better prognosis. Acta Neuropathol 2013; 126: 443-51 
40 Sahm F, von Deimling A. Farewell to oligoastrocytoma: response to letters. Acta Neuropathol 2014:

41 Reuss DE, Sahm F, Schrimpf D, Wiestler B, Capper D, Koelsche C, Schweizer L, Korshunov A, Jones DT, Hovestadt V, Mittelbronn M, Schittenhelm J, Herold-Mende C, Unterberg A, Platten M, Weller M, Wick W, Pfister SM, von Deimling A. ATRX and IDH1$\mathrm{R} 132 \mathrm{H}$ immunohistochemistry with subsequent copy number analysis and IDH sequencing as a basis for an "integrated" diagnostic approach for adult astrocytoma, oligodendroglioma and glioblastoma. Acta Neuropathol 2014:

42 Griffin CA, Burger P, Morsberger L, Yonescu R, Swierczynski S, Weingart JD, Murphy KM. Identification of $\operatorname{der}(1 ; 19)(q 10 ; p 10)$ in five oligodendrogliomas suggests mechanism of concurrent 1p and 19q loss. J Neuropathol Exp Neurol 2006; 65: 988-94

43 Jenkins RB, Blair H, Ballman KV, Giannini C, Arusell RM, Law M, Flynn H, Passe S, Felten S, Brown PD, Shaw EG, Buckner JC. A t $(1 ; 19)(q 10 ; p 10)$ mediates the combined deletions of $1 p$ and $19 q$ and predicts a better prognosis of patients with oligodendroglioma. Cancer Res 2006; 66: 9852-61

44 Jiang H, Ren X, Cui X, Wang J, Jia W, Zhou Z, Lin S. 1p/19q codeletion and IDH1/2 mutation identified a subtype of anaplastic oligoastrocytomas with prognosis as favorable as anaplastic oligodendrogliomas. Neuro Oncol 2013; 15: 775-82

45 Frenel JS, Leux C, Loussouarn D, Le Loupp AG, Leclair F, Aumont M, Mervoyer A, Martin S, Denis MG, Campone M. Combining two biomarkers, IDH1/2 mutations and 1p/19q codeletion, to stratify anaplastic oligodendroglioma in three groups: a single-center experience. J Neurooncol 2013; 114: 85-91

46 Preusser M, Capper D, Hartmann C. IDH testing in diagnostic neuropathology: review and practical guideline article invited by the Euro-CNS research committee. Clin Neuropathol 2011; 30: 217-30

47 Leu S, von Felten S, Frank S, Vassella E, Vajtai I, Taylor E, Schulz M, Hutter G, Hench J, Schucht P, Boulay JL, Mariani L. IDH/MGMT-driven molecular classification of low-grade glioma is a strong predictor for long-term survival. Neuro Oncol 2013; 15: 469-79

48 SongTao Q, Lei Y, Si G, YanQing D, HuiXia H, XueLin Z, LanXiao W, Fei Y. IDH mutations predict longer survival and response to temozolomide in secondary glioblastoma. Cancer Sci 2012; 103: 269-73

49 Parsons DW, Jones S, Zhang X, Lin JC, Leary RJ, Angenendt P, Mankoo P, Carter H, Siu IM, Gallia GL, Olivi A, McLendon R, Rasheed BA, Keir S, Nikolskaya T, Nikolsky Y, Busam DA, Tekleab H, Diaz LA, Jr., Hartigan J, Smith DR, Strausberg RL, Marie SK, Shinjo SM, Yan H, Riggins GJ, Bigner DD, Karchin R, Papadopoulos N, Parmigiani G, Vogelstein B, Velculescu VE, Kinzler KW. An integrated genomic analysis of human glioblastoma multiforme. Science 2008; 321: 1807-12

50 Sanson M, Marie Y, Paris S, Idbaih A, Laffaire J, Ducray F, El Hallani S, Boisselier B, Mokhtari K, Hoang-Xuan K, Delattre JY. Isocitrate dehydrogenase 1 codon 132 mutation is an important prognostic biomarker in gliomas. J Clin Oncol 2009; 27: 4150-4

51 Dahlrot RH, Kristensen BW, Hjelmborg J, Herrstedt J, Hansen S. A population-based study of high-grade gliomas and mutated isocitrate dehydrogenase 1. Int J Clin Exp Pathol 2013; 6: 31-40

52 Houillier C, Wang X, Kaloshi G, Mokhtari K, Guillevin R, Laffaire J, Paris S, Boisselier B, Idbaih A, Laigle-Donadey F, Hoang-Xuan K, Sanson M, Delattre JY. IDH1 or IDH2 mutations predict longer survival and response to temozolomide in low-grade gliomas. Neurology 2010; 75: 1560-6

53 Kim YH, Nobusawa S, Mittelbronn M, Paulus W, Brokinkel B, Keyvani K, Sure U, Wrede K, Nakazato Y, Tanaka Y, Vital A, Mariani L, Stawski R, Watanabe T, De Girolami U, Kleihues $\mathrm{P}$, Ohgaki H. Molecular classification of low-grade diffuse gliomas. Am J Pathol 2010; 177: 2708-14 
54 Dahlrot RH, Kristensen BW, Hjelmborg J, Herrstedt J, Hansen S. A population-based study of low-grade gliomas and mutated isocitrate dehydrogenase 1 (IDH1). J Neurooncol 2013:

55 Ahmadi R, Stockhammer F, Becker N, Hohlen K, Misch M, Christians A, Dictus C, Herold-Mende C, Capper D, Unterberg A, von Deimling A, Wick W, Hartmann C. No prognostic value of IDH1 mutations in a series of $100 \mathrm{WHO}$ grade II astrocytomas. J Neurooncol 2012:

56 Thon N, Eigenbrod S, Kreth S, Lutz J, Tonn JC, Kretzschmar H, Peraud A, Kreth FW. IDH1 mutations in grade II astrocytomas are associated with unfavorable progression-free survival and prolonged postrecurrence survival. Cancer 2012; 118: 452-60

57 Wick W, Meisner C, Hentschel B, Platten M, Schilling A, Wiestler B, Sabel MC, Koeppen S, Ketter R, Weiler M, Tabatabai G, von Deimling A, Gramatzki D, Westphal M, Schackert G, Loeffler M, Simon M, Reifenberger G, Weller M. Prognostic or predictive value of MGMT promoter methylation in gliomas depends on IDH1 mutation. Neurology 2013; 81: $1515-22$

58 Kato Y, Jin G, Kuan CT, McLendon RE, Yan H, Bigner DD. A monoclonal antibody IMab-1 specifically recognizes IDH1R132H, the most common glioma-derived mutation. Biochem Biophys Res Commun 2009; 390: 547-51

59 Capper D, Sahm F, Hartmann C, Meyermann R, von Deimling A, Schittenhelm J. Application of mutant IDH1 antibody to differentiate diffuse glioma from nonneoplastic central nervous system lesions and therapy-induced changes. Am J Surg Pathol 2010; 34: $1199-204$

60 van den Bent MJ, Hartmann C, Preusser M, Strobel T, Dubbink HJ, Kros JM, von Deimling A, Boisselier B, Sanson M, Halling KC, Diefes KL, Aldape K, Giannini C. Interlaboratory comparison of IDH mutation detection. J Neurooncol 2013; 112: 173-8 61 Balss J, Meyer J, Mueller W, Korshunov A, Hartmann C, von Deimling A. Analysis of the IDH1 codon 132 mutation in brain tumors. Acta Neuropathol 2008; 116: 597-602 62 Hartmann C, Meyer J, Balss J, Capper D, Mueller W, Christians A, Felsberg J, Wolter M, Mawrin C, Wick W, Weller M, Herold-Mende C, Unterberg A, Jeuken JW, Wesseling P, Reifenberger $\mathrm{G}$, von Deimling A. Type and frequency of IDH1 and IDH2 mutations are related to astrocytic and oligodendroglial differentiation and age: a study of 1,010 diffuse gliomas. Acta Neuropathol 2009; 118: 469-74

63 Ichimura K, Pearson DM, Kocialkowski S, Backlund LM, Chan R, Jones DT, Collins VP. IDH1 mutations are present in the majority of common adult gliomas but rare in primary glioblastomas. Neuro Oncol 2009; 11: 341-7

64 Korshunov A, Meyer J, Capper D, Christians A, Remke M, Witt H, Pfister S, von Deimling A, Hartmann C. Combined molecular analysis of BRAF and IDH1 distinguishes pilocytic astrocytoma from diffuse astrocytoma. Acta Neuropathol 2009; 118: 401-5 65 Nobusawa S, Watanabe T, Kleihues P, Ohgaki H. IDH1 mutations as molecular signature and predictive factor of secondary glioblastomas. Clin Cancer Res 2009; 15: 6002-7 66 Ohgaki $\mathrm{H}$, Kleihues $\mathrm{P}$. Genetic alterations and signaling pathways in the evolution of gliomas. Cancer Sci 2009; 100: 2235-41

67 Yan H, Parsons DW, Jin G, McLendon R, Rasheed BA, Yuan W, Kos I, Batinic-Haberle I, Jones S, Riggins GJ, Friedman H, Friedman A, Reardon D, Herndon J, Kinzler KW, Velculescu VE, Vogelstein B, Bigner DD. IDH1 and IDH2 mutations in gliomas. N Engl J Med 2009; 360: 765-73

68 Watanabe T, Nobusawa S, Kleihues P, Ohgaki H. IDH1 mutations are early events in the development of astrocytomas and oligodendrogliomas. Am J Pathol 2009; 174: 1149-53 69 Watanabe T, Vital A, Nobusawa S, Kleihues P, Ohgaki H. Selective acquisition of IDH1 R132C mutations in astrocytomas associated with Li-Fraumeni syndrome. Acta Neuropathol 2009; 117: 653-6 
70 Capper D, Zentgraf H, Balss J, Hartmann C, von Deimling A. Monoclonal antibody specific for IDH1 R132H mutation. Acta Neuropathol 2009; 118: 599-601

71 Cairns RA, Harris IS, Mak TW. Regulation of cancer cell metabolism. Nat Rev Cancer 2011; 11: 85-95

72 Ye D, Ma S, Xiong Y, Guan KL. R-2-hydroxyglutarate as the key effector of IDH mutations promoting oncogenesis. Cancer Cell 2013; 23: 274-6

73 Losman JA, Kaelin WG, Jr. What a difference a hydroxyl makes: mutant IDH, (R)-2hydroxyglutarate, and cancer. Genes Dev 2013; 27: 836-52

74 Jones PA, Baylin SB. The epigenomics of cancer. Cell 2007; 128: 683-92

75 Ichimura K. Molecular pathogenesis of IDH mutations in gliomas. Brain Tumor Pathol 2012; 29: 131-9

76 Turcan S, Rohle D, Goenka A, Walsh LA, Fang F, Yilmaz E, Campos C, Fabius AW, Lu C, Ward PS, Thompson CB, Kaufman A, Guryanova O, Levine R, Heguy A, Viale A, Morris LG, Huse JT, Mellinghoff IK, Chan TA. IDH1 mutation is sufficient to establish the glioma hypermethylator phenotype. Nature 2012; 483: 479-83

77 Noushmehr H, Weisenberger DJ, Diefes K, Phillips HS, Pujara K, Berman BP, Pan F, Pelloski CE, Sulman EP, Bhat KP, Verhaak RG, Hoadley KA, Hayes DN, Perou CM, Schmidt HK, Ding L, Wilson RK, Van Den Berg D, Shen H, Bengtsson H, Neuvial P, Cope LM, Buckley J, Herman JG, Baylin SB, Laird PW, Aldape K. Identification of a CpG island methylator phenotype that defines a distinct subgroup of glioma. Cancer Cell 2010; 17: 510-22 78 Bady P, Sciuscio D, Diserens AC, Bloch J, van den Bent MJ, Marosi C, Dietrich PY, Weller M, Mariani L, Heppner FL, McDonald DR, Lacombe D, Stupp R, Delorenzi M, Hegi ME. MGMT methylation analysis of glioblastoma on the Infinium methylation BeadChip identifies two distinct $\mathrm{CpG}$ regions associated with gene silencing and outcome, yielding a prediction model for comparisons across datasets, tumor grades, and CIMP-status. Acta Neuropathol 2012; 124: 547-60

79 Sturm D, Witt $H$, Hovestadt $V$, Khuong-Quang DA, Jones DT, Konermann C, Pfaff E, Tonjes M, Sill M, Bender S, Kool M, Zapatka M, Becker N, Zucknick M, Hielscher T, Liu XY, Fontebasso AM, Ryzhova M, Albrecht S, Jacob K, Wolter M, Ebinger M, Schuhmann MU, van Meter T, Fruhwald MC, Hauch H, Pekrun A, Radlwimmer B, Niehues T, von Komorowski G, Durken M, Kulozik AE, Madden J, Donson A, Foreman NK, Drissi R, Fouladi M, Scheurlen W, von Deimling A, Monoranu C, Roggendorf W, Herold-Mende C, Unterberg A, Kramm CM, Felsberg J, Hartmann C, Wiestler B, Wick W, Milde T, Witt O, Lindroth AM, Schwartzentruber J, Faury D, Fleming A, Zakrzewska M, Liberski PP, Zakrzewski K, Hauser P, Garami M, Klekner A, Bognar L, Morrissy S, Cavalli F, Taylor MD, van Sluis P, Koster J, Versteeg R, Volckmann R, Mikkelsen T, Aldape K, Reifenberger G, Collins VP, Majewski J, Korshunov A, Lichter P, Plass C, Jabado N, Pfister SM. Hotspot mutations in H3F3A and IDH1 define distinct epigenetic and biological subgroups of glioblastoma. Cancer Cell 2012; 22: 425-37

80 Wiestler B, Capper D, Hovestadt V, Sill M, Jones DT, Hartmann C, Felsberg J, Platten M, Feiden W, Keyvani K, Pfister SM, Wiestler OD, Meyermann R, Reifenberger G, Pietsch T, von Deimling A, Weller M, Wick W. Assessing CpG island methylator phenotype, 1p/19q codeletion, and MGMT promoter methylation from epigenome-wide data in the biomarker cohort of the NOA-04 trial. Neuro Oncol 2014; 16: 1630-8

81 Kannan K, Inagaki A, Silber J, Gorovets D, Zhang J, Kastenhuber ER, Heguy A, Petrini $\mathrm{JH}$, Chan TA, Huse JT. Whole-exome sequencing identifies ATRX mutation as a key molecular determinant in lower-grade glioma. Oncotarget 2012; 3: 1194-203

82 Liu XY, Gerges N, Korshunov A, Sabha N, Khuong-Quang DA, Fontebasso AM, Fleming A, Hadjadj D, Schwartzentruber J, Majewski J, Dong Z, Siegel P, Albrecht S, Croul S, Jones DT, Kool M, Tonjes M, Reifenberger G, Faury D, Zadeh G, Pfister S, Jabado N. Frequent ATRX mutations and loss of expression in adult diffuse astrocytic tumors carrying IDH1/IDH2 and TP53 mutations. Acta Neuropathol 2012; 124: 615-25 
83 Gibbons RJ, Picketts DJ, Villard L, Higgs DR. Mutations in a putative global transcriptional regulator cause $X$-linked mental retardation with alpha-thalassemia (ATR-X syndrome). Cell 1995; 80: 837-45

84 Lewis PW, Elsaesser SJ, Noh KM, Stadler SC, Allis CD. Daxx is an H3.3-specific histone chaperone and cooperates with ATRX in replication-independent chromatin assembly at telomeres. Proc Natl Acad Sci U S A 2010; 107: 14075-80

85 Jiao Y, Shi C, Edil BH, de Wilde RF, Klimstra DS, Maitra A, Schulick RD, Tang LH, Wolfgang CL, Choti MA, Velculescu VE, Diaz LA, Jr., Vogelstein B, Kinzler KW, Hruban RH, Papadopoulos N. DAXX/ATRX, MEN1, and mTOR pathway genes are frequently altered in pancreatic neuroendocrine tumors. Science 2011; 331: 1199-203

86 Cheung NK, Zhang J, Lu C, Parker M, Bahrami A, Tickoo SK, Heguy A, Pappo AS, Federico S, Dalton J, Cheung IY, Ding L, Fulton R, Wang J, Chen X, Becksfort J, Wu J, Billups CA, Ellison D, Mardis ER, Wilson RK, Downing JR, Dyer MA. Association of age at diagnosis and genetic mutations in patients with neuroblastoma. JAMA 2012; 307: 1062-71

87 Heaphy CM, de Wilde RF, Jiao Y, Klein AP, Edil BH, Shi C, Bettegowda C, Rodriguez FJ, Eberhart CG, Hebbar S, Offerhaus GJ, McLendon R, Rasheed BA, He Y, Yan H, Bigner DD, ObaShinjo SM, Marie SK, Riggins GJ, Kinzler KW, Vogelstein B, Hruban RH, Maitra A, Papadopoulos N, Meeker AK. Altered telomeres in tumors with ATRX and DAXX mutations. Science 2011; 333: 425

88 Blough MD, Al-Najjar M, Chesnelong C, Binding CE, Rogers AD, Luchman HA, Kelly JJ, Fliegel L, Morozova O, Yip S, Marra M, Weiss S, Chan JA, Cairncross JG. DNA hypermethylation and 1p Loss silence NHE-1 in oligodendroglioma. Ann Neurol 2012; 71: $845-9$

89 Bettegowda C, Agrawal N, Jiao Y, Sausen M, Wood LD, Hruban RH, Rodriguez FJ, Cahill DP, McLendon R, Riggins G, Velculescu VE, Oba-Shinjo SM, Marie SK, Vogelstein B, Bigner D, Yan H, Papadopoulos N, Kinzler KW. Mutations in CIC and FUBP1 contribute to human oligodendroglioma. Science 2011; 333: 1453-5

90 Yip S, Butterfield YS, Morozova O, Chittaranjan S, Blough MD, An J, Birol I, Chesnelong C, Chiu R, Chuah E, Corbett R, Docking R, Firme M, Hirst M, Jackman S, Karsan A, Li H, Louis DN, Maslova A, Moore R, Moradian A, Mungall KL, Perizzolo M, Qian J, Roldan G, Smith EE, Tamura-Wells J, Thiessen N, Varhol R, Weiss S, Wu W, Young S, Zhao Y, Mungall AJ, Jones SJ, Morin GB, Chan JA, Cairncross JG, Marra MA. Concurrent CIC mutations, IDH mutations, and $1 p / 19 q$ loss distinguish oligodendrogliomas from other cancers. J Pathol 2012; 226: 7-16

91 Baumgarten $P$, Harter PN, Tonjes M, Capper D, Blank AE, Sahm F, von Deimling A, Kolluru V, Schwamb B, Rabenhorst U, Starzetz T, Kogel D, Rieker RJ, Plate KH, Ohgaki H, Radlwimmer B, Zornig M, Mittelbronn M. Loss of FUBP1 expression in gliomas predicts FUBP1 mutation and is associated with oligodendroglial differentiation, IDH1 mutation and 1p/19q loss of heterozygosity. Neuropathol Appl Neurobiol 2014; 40: 205-16

92 Rabenhorst U, Beinoraviciute-Kellner R, Brezniceanu ML, Joos S, Devens F, Lichter P, Rieker RJ, Trojan J, Chung HJ, Levens DL, Zornig M. Overexpression of the far upstream element binding protein 1 in hepatocellular carcinoma is required for tumor growth. Hepatology 2009; 50: 1121-9

93 Hsiao HH, Nath A, Lin CY, Folta-Stogniew EJ, Rhoades E, Braddock DT. Quantitative characterization of the interactions among c-myc transcriptional regulators FUSE, FBP, and FIR. Biochemistry 2010; 49: 4620-34

94 Duncan R, Bazar L, Michelotti G, Tomonaga T, Krutzsch H, Avigan M, Levens D. A sequence-specific, single-strand binding protein activates the far upstream element of c-myc and defines a new DNA-binding motif. Genes Dev 1994; 8: 465-80

95 Roch F, Jimenez G, Casanova J. EGFR signalling inhibits Capicua-dependent repression during specification of Drosophila wing veins. Development 2002; 129: 993-1002 
96 Nagaishi M, Suzuki A, Nobusawa S, Yokoo H, Nakazato Y. Alpha-internexin and altered $\mathrm{CIC}$ expression as a supportive diagnostic marker for oligodendroglial tumors with the 1p/19q co-deletion. Brain Tumor Pathol 2013:

97 Killela PJ, Pirozzi CJ, Healy P, Reitman ZJ, Lipp E, Rasheed BA, Yang R, Diplas BH, Wang Z, Greer PK, Zhu H, Wang CY, Carpenter AB, Friedman H, Friedman AH, Keir ST, He J, He Y, McLendon RE, Herndon JE, 2nd, Yan H, Bigner DD. Mutations in IDH1, IDH2, and in the TERT promoter define clinically distinct subgroups of adult malignant gliomas. Oncotarget 2014; 5: 1515-25

98 Nonoguchi N, Ohta T, Oh JE, Kim YH, Kleihues P, Ohgaki H. TERT promoter mutations in primary and secondary glioblastomas. Acta Neuropathol 2013; 126: 931-7

99 Koelsche C, Sahm F, Capper D, Reuss D, Sturm D, Jones DT, Kool M, Northcott PA, Wiestler B, Bohmer K, Meyer J, Mawrin C, Hartmann C, Mittelbronn M, Platten M, Brokinkel B, Seiz M, Herold-Mende C, Unterberg A, Schittenhelm J, Weller M, Pfister S, Wick W, Korshunov A, von Deimling A. Distribution of TERT promoter mutations in pediatric and adult tumors of the nervous system. Acta Neuropathol 2013; 126: 907-15

100 Vinagre J, Almeida A, Populo H, Batista R, Lyra J, Pinto V, Coelho R, Celestino R, Prazeres H, Lima L, Melo M, da Rocha AG, Preto A, Castro P, Castro L, Pardal F, Lopes JM, Santos LL, Reis RM, Cameselle-Teijeiro J, Sobrinho-Simoes M, Lima J, Maximo V, Soares P. Frequency of TERT promoter mutations in human cancers. Nat Commun 2013; 4: 2185 101 Killela PJ, Reitman ZJ, Jiao Y, Bettegowda C, Agrawal N, Diaz LA, Jr., Friedman AH, Friedman H, Gallia GL, Giovanella BC, Grollman AP, He TC, He Y, Hruban RH, Jallo GI, Mandahl N, Meeker AK, Mertens F, Netto GJ, Rasheed BA, Riggins GJ, Rosenquist TA, Schiffman M, Shih le M, Theodorescu D, Torbenson MS, Velculescu VE, Wang TL, Wentzensen N, Wood LD, Zhang M, McLendon RE, Bigner DD, Kinzler KW, Vogelstein B, Papadopoulos $\mathrm{N}$, Yan $\mathrm{H}$. TERT promoter mutations occur frequently in gliomas and a subset of tumors derived from cells with low rates of self-renewal. Proc Natl Acad Sci U S A 2013; 110: 6021-6

102 Davies H, Bignell GR, Cox C, Stephens P, Edkins S, Clegg S, Teague J, Woffendin H, Garnett MJ, Bottomley W, Davis N, Dicks E, Ewing R, Floyd Y, Gray K, Hall S, Hawes R, Hughes J, Kosmidou V, Menzies A, Mould C, Parker A, Stevens C, Watt S, Hooper S, Wilson R, Jayatilake H, Gusterson BA, Cooper C, Shipley J, Hargrave D, Pritchard-Jones K, Maitland N, Chenevix-Trench G, Riggins GJ, Bigner DD, Palmieri G, Cossu A, Flanagan A, Nicholson A, Ho JW, Leung SY, Yuen ST, Weber BL, Seigler HF, Darrow TL, Paterson H, Marais R, Marshall CJ, Wooster R, Stratton MR, Futreal PA. Mutations of the BRAF gene in human cancer. Nature 2002; 417: 949-54

103 Dias-Santagata D, Akhavanfard S, David SS, Vernovsky K, Kuhlmann G, Boisvert SL, Stubbs H, McDermott U, Settleman J, Kwak EL, Clark JW, Isakoff SJ, Sequist LV, Engelman JA, Lynch TJ, Haber DA, Louis DN, Ellisen LW, Borger DR, lafrate AJ. Rapid targeted mutational analysis of human tumours: a clinical platform to guide personalized cancer medicine. EMBO Mol Med 2010; 2: 146-58

104 Schindler G, Capper D, Meyer J, Janzarik W, Omran H, Herold-Mende C, Schmieder K, Wesseling P, Mawrin C, Hasselblatt M, Louis DN, Korshunov A, Pfister S, Hartmann C, Paulus $W$, Reifenberger $G$, von Deimling A. Analysis of BRAF V600E mutation in 1,320 nervous system tumors reveals high mutation frequencies in pleomorphic xanthoastrocytoma, ganglioglioma and extra-cerebellar pilocytic astrocytoma. Acta Neuropathol 2011:

105 Brastianos PK, Taylor-Weiner A, Manley PE, Jones RT, Dias-Santagata D, Thorner AR, Lawrence MS, Rodriguez FJ, Bernardo LA, Schubert L, Sunkavalli A, Shillingford N, Calicchio ML, Lidov HG, Taha H, Martinez-Lage M, Santi M, Storm PB, Lee JY, Palmer JN, Adappa ND, Scott RM, Dunn IF, Laws ER, Jr., Stewart C, Ligon KL, Hoang MP, Van Hummelen P, Hahn WC, Louis DN, Resnick AC, Kieran MW, Getz G, Santagata S. Exome sequencing identifies BRAF mutations in papillary craniopharyngiomas. Nat Genet 2014; 46: 161-5 
106 Schweizer L, Capper D, Holsken A, Fahlbusch R, Flitsch J, Buchfelder M, HeroldMende C, von Deimling A, Buslei R. BRAF V600E analysis for the differentiation of papillary Craniopharyngiomas and Rathke's Cleft Cysts. Neuropathol Appl Neurobiol 2014:

107 Dias-Santagata D, Lam Q, Vernovsky K, Vena N, Lennerz JK, Borger DR, Batchelor TT, Ligon KL, lafrate AJ, Ligon AH, Louis DN, Santagata S. BRAF V600E mutations are common in pleomorphic xanthoastrocytoma: diagnostic and therapeutic implications. PLoS One 2011; 6: e17948

108 Capper D, Berghoff AS, Magerle M, Ilhan A, Wohrer A, Hackl M, Pichler J, Pusch S, Meyer J, Habel A, Petzelbauer $P$, Birner $P$, von Deimling A, Preusser $M$.

Immunohistochemical testing of BRAF V600E status in 1,120 tumor tissue samples of patients with brain metastases. Acta Neuropathol 2012; 123: 223-33

109 Chappe C, Padovani L, Scavarda D, Forest F, Nanni-Metellus I, Loundou A, Mercurio $S$, Fina F, Lena G, Colin C, Figarella-Branger D. Dysembryoplastic neuroepithelial tumors share with pleomorphic xanthoastrocytomas and gangliogliomas BRAF(V600E) mutation and expression. Brain Pathol 2013; 23: 574-83

110 Koelsche C, Sahm F, Paulus W, Mittelbronn M, Giangaspero F, Antonelli M, Meyer J, Lasitschka F, von Deimling A, Reuss D. BRAF V600E expression and distribution in desmoplastic infantile astrocytoma/ganglioglioma. Neuropathol Appl Neurobiol 2014; 40: 337-44

111 Koelsche C, Wohrer A, Jeibmann A, Schittenhelm J, Schindler G, Preusser M, Lasitschka F, von Deimling A, Capper D. Mutant BRAF V600E protein in ganglioglioma is predominantly expressed by neuronal tumor cells. Acta Neuropathol 2013; 125: 891-900 112 Karabagli P, Karabagli H, Kose D, Kocak N, Etus V, Koksal Y. Desmoplastic noninfantile astrocytic tumor with BRAF V600E mutation. Brain Tumor Pathol 2014:

113 Myung JK, Cho H, Park CK, Kim SK, Lee SH, Park SH. Analysis of the BRAF(V600E) Mutation in Central Nervous System Tumors. Transl Oncol 2012; 5: 430-6

114 Kleinschmidt-DeMasters BK, Aisner DL, Birks DK, Foreman NK. Epithelioid GBMs show a high percentage of BRAF V600E mutation. Am J Surg Pathol 2013; 37: 685-98

115 Dahiya S, Emnett RJ, Haydon DH, Leonard JR, Phillips JJ, Perry A, Gutmann DH. BRAFV600E mutation in pediatric and adult glioblastoma. Neuro Oncol 2014; 16: 318-9

116 Aisner DL, Newell KL, Pollack AG, Kleinschmidt-Demasters BK, Steinberg GK, Smyth LT, Vogel H. Composite pleomorphic xanthoastrocytoma-epithelioid glioneuronal tumor with BRAF V600E mutation - report of three cases. Clin Neuropathol 2014; 33: 112-21

117 Nobusawa S, Hirato J, Kurihara H, Ogawa A, Okura N, Nagaishi M, Ikota H, Yokoo H, Nakazato Y. Intratumoral heterogeneity of genomic imbalance in a case of epithelioid glioblastoma with BRAF V600E mutation. Brain Pathol 2014; 24: 239-46

118 Dahiya S, Haydon DH, Alvarado D, Gurnett CA, Gutmann DH, Leonard JR. BRAF(V600E) mutation is a negative prognosticator in pediatric ganglioglioma. Acta Neuropathol 2013; 125: 901-10

119 Chi AS, Batchelor TT, Yang D, Dias-Santagata D, Borger DR, Ellisen LW, lafrate AJ, Louis DN. BRAF V600E mutation identifies a subset of low-grade diffusely infiltrating gliomas in adults. J Clin Oncol 2013; 31: e233-6

120 Capper D, Preusser M, Habel A, Sahm F, Ackermann U, Schindler G, Pusch S, Mechtersheimer $G$, Zentgraf $H$, von Deimling A. Assessment of BRAF V600E mutation status by immunohistochemistry with a mutation-specific monoclonal antibody. Acta Neuropathol 2011; 122: 11-9

121 Robinson MJ, Cobb MH. Mitogen-activated protein kinase pathways. Curr Opin Cell Biol 1997; 9: 180-6

122 Peyssonnaux C, Eychene A. The Raf/MEK/ERK pathway: new concepts of activation. Biol Cell 2001; 93: 53-62 
123 Jones DT, Kocialkowski S, Liu L, Pearson DM, Backlund LM, Ichimura K, Collins VP. Tandem duplication producing a novel oncogenic BRAF fusion gene defines the majority of pilocytic astrocytomas. Cancer Res 2008; 68: 8673-7

124 Tatevossian RG, Lawson AR, Forshew T, Hindley GF, Ellison DW, Sheer D. MAPK pathway activation and the origins of pediatric low-grade astrocytomas. J Cell Physiol 2010; 222: 509-14

125 Forshew T, Tatevossian RG, Lawson AR, Ma J, Neale G, Ogunkolade BW, Jones TA, Aarum J, Dalton J, Bailey S, Chaplin T, Carter RL, Gajjar A, Broniscer A, Young BD, Ellison DW, Sheer D. Activation of the ERK/MAPK pathway: a signature genetic defect in posterior fossa pilocytic astrocytomas. J Pathol 2009; 218: 172-81

126 Horbinski C, Hamilton RL, Nikiforov Y, Pollack IF. Association of molecular alterations, including BRAF, with biology and outcome in pilocytic astrocytomas. Acta Neuropathol 2010:

127 Jacob K, Albrecht S, Sollier C, Faury D, Sader E, Montpetit A, Serre D, Hauser P, Garami M, Bognar L, Hanzely Z, Montes JL, Atkinson J, Farmer JP, Bouffet E, Hawkins C, Tabori U, Jabado N. Duplication of 7q34 is specific to juvenile pilocytic astrocytomas and a hallmark of cerebellar and optic pathway tumours. Br J Cancer 2009; 101: 722-33

128 Kim YH, Nonoguchi N, Paulus W, Brokinkel B, Keyvani K, Sure U, Wrede K, Mariani L, Giangaspero F, Tanaka Y, Nakazato Y, Vital A, Mittelbronn M, Perry A, Ohgaki H. Frequent BRAF gain in low-grade diffuse gliomas with 1p/19q loss. Brain Pathol 2012; 22: 834-40 129 Lawson AR, Tatevossian RG, Phipps KP, Picker SR, Michalski A, Sheer D, Jacques TS, Forshew T. RAF gene fusions are specific to pilocytic astrocytoma in a broad paediatric brain tumour cohort. Acta Neuropathol 2010; 120: 271-3

130 Meyer C, Marschalek R. LDI-PCR: identification of known and unknown gene fusions of the human MLL gene. Methods Mol Biol 2009; 538: 71-83

131 Jones DT, Kocialkowski S, Liu L, Pearson DM, Ichimura K, Collins VP. Oncogenic RAF1 rearrangement and a novel BRAF mutation as alternatives to KIAA1549:BRAF fusion in activating the MAPK pathway in pilocytic astrocytoma. Oncogene 2009; 28: 2119-23

132 Strout MP, Marcucci G, Bloomfield CD, Caligiuri MA. The partial tandem duplication of ALL1 (MLL) is consistently generated by Alu-mediated homologous recombination in acute myeloid leukemia. Proc Natl Acad Sci U S A 1998; 95: 2390-5

133 Roth JJ, Santi M, Rorke-Adams LB, Harding BN, Busse TM, Tooke LS, Biegel JA.

Diagnostic application of high resolution single nucleotide polymorphism array analysis for children with brain tumors. Cancer Genet 2014; 207: 111-23

134 Jones DT, Hutter B, Jager N, Korshunov A, Kool M, Warnatz HJ, Zichner T, Lambert SR, Ryzhova M, Quang DA, Fontebasso AM, Stutz AM, Hutter S, Zuckermann M, Sturm D, Gronych J, Lasitschka B, Schmidt S, Seker-Cin H, Witt H, Sultan M, Ralser M, Northcott PA, Hovestadt V, Bender S, Pfaff E, Stark S, Faury D, Schwartzentruber J, Majewski J, Weber UD, Zapatka M, Raeder B, Schlesner M, Worth CL, Bartholomae CC, von Kalle C, Imbusch CD, Radomski S, Lawerenz C, van Sluis $P$, Koster J, Volckmann R, Versteeg R, Lehrach $H$, Monoranu $C$, Winkler $B$, Unterberg A, Herold-Mende $C$, Milde $T$, Kulozik AE, Ebinger $M$, Schuhmann MU, Cho YJ, Pomeroy SL, von Deimling A, Witt O, Taylor MD, Wolf S, Karajannis MA, Eberhart CG, Scheurlen W, Hasselblatt M, Ligon KL, Kieran MW, Korbel JO, Yaspo ML, Brors B, Felsberg J, Reifenberger G, Collins VP, Jabado N, Eils R, Lichter P, Pfister SM. Recurrent somatic alterations of FGFR1 and NTRK2 in pilocytic astrocytoma. Nat Genet 2013; 45: 927-32

135 Weller M, Stupp R, Reifenberger G, Brandes AA, van den Bent MJ, Wick W, Hegi ME. MGMT promoter methylation in malignant gliomas: ready for personalized medicine? Nat Rev Neurol 2010; 6: 39-51

136 Hegi ME, Diserens AC, Gorlia T, Hamou MF, de Tribolet N, Weller M, Kros JM, Hainfellner JA, Mason W, Mariani L, Bromberg JE, Hau P, Mirimanoff RO, Cairncross JG, 
Janzer RC, Stupp R. MGMT gene silencing and benefit from temozolomide in glioblastoma. N Engl J Med 2005; 352: 997-1003

137 Stupp R, Hegi ME, Neyns B, Goldbrunner R, Schlegel U, Clement PM, Grabenbauer GG, Ochsenbein AF, Simon M, Dietrich PY, Pietsch T, Hicking C, Tonn JC, Diserens AC, Pica A, Hermisson M, Krueger S, Picard M, Weller M. Phase I/Ila study of cilengitide and temozolomide with concomitant radiotherapy followed by cilengitide and temozolomide maintenance therapy in patients with newly diagnosed glioblastoma. J Clin Oncol 2010; 28:

2712-8

138 Stupp R, Hegi ME, Gorlia T, Erridge SC, Perry J, Hong YK, Aldape KD, Lhermitte B, Pietsch T, Grujicic D, Steinbach JP, Wick W, Tarnawski R, Nam DH, Hau P, Weyerbrock A, Taphoorn MJ, Shen CC, Rao N, Thurzo L, Herrlinger U, Gupta T, Kortmann RD, Adamska K, McBain C, Brandes AA, Tonn JC, Schnell O, Wiegel T, Kim CY, Nabors LB, Reardon DA, van den Bent MJ, Hicking C, Markivskyy A, Picard M, Weller M. Cilengitide combined with standard treatment for patients with newly diagnosed glioblastoma with methylated MGMT promoter (CENTRIC EORTC 26071-22072 study): a multicentre, randomised, open-label, phase 3 trial. Lancet Oncol 2014; 15: 1100-8

139 Chinot OL. Cilengitide in glioblastoma: when did it fail? Lancet Oncol 2014; 15: 10445

140 Stupp R, Mason WP, van den Bent MJ, Weller M, Fisher B, Taphoorn MJ, Belanger K, Brandes AA, Marosi C, Bogdahn U, Curschmann J, Janzer RC, Ludwin SK, Gorlia T, Allgeier A, Lacombe D, Cairncross JG, Eisenhauer E, Mirimanoff RO. Radiotherapy plus concomitant and adjuvant temozolomide for glioblastoma. N Engl J Med 2005; 352: 987-96

141 Reifenberger G, Hentschel B, Felsberg J, Schackert G, Simon M, Schnell O, Westphal M, Wick W, Pietsch T, Loeffler M, Weller M. Predictive impact of MGMT promoter methylation in glioblastoma of the elderly. Int J Cancer 2012; 131: 1342-50

142 Gallego Perez-Larraya J, Ducray F, Chinot O, Catry-Thomas I, Taillandier L, Guillamo JS, Campello C, Monjour A, Cartalat-Carel S, Barrie M, Huchet A, Beauchesne P, Matta M, Mokhtari K, Tanguy ML, Honnorat J, Delattre JY. Temozolomide in elderly patients with newly diagnosed glioblastoma and poor performance status: an ANOCEF phase II trial. J Clin Oncol 2011; 29: 3050-5

143 Malmstrom A, Gronberg BH, Marosi C, Stupp R, Frappaz D, Schultz H, Abacioglu U, Tavelin B, Lhermitte B, Hegi ME, Rosell J, Henriksson R. Temozolomide versus standard 6week radiotherapy versus hypofractionated radiotherapy in patients older than 60 years with glioblastoma: the Nordic randomised, phase 3 trial. Lancet Oncol 2012; 13: 916-26 144 Armstrong TS, Wefel JS, Wang M, Gilbert MR, Won M, Bottomley A, Mendoza TR, Coens C, Werner-Wasik M, Brachman DG, Choucair AK, Mehta M. Net clinical benefit analysis of radiation therapy oncology group 0525: a phase III trial comparing conventional adjuvant temozolomide with dose-intensive temozolomide in patients with newly diagnosed glioblastoma. J Clin Oncol 2013; 31: 4076-84

145 Weller M, Pfister SM, Wick W, Hegi ME, Reifenberger G, Stupp R. Molecular neurooncology in clinical practice: a new horizon. Lancet Oncol 2013; 14: e370-9

146 Preusser M, Charles Janzer R, Felsberg J, Reifenberger G, Hamou MF, Diserens AC, Stupp R, Gorlia T, Marosi C, Heinzl H, Hainfellner JA, Hegi M. Anti-O6-methylguaninemethyltransferase (MGMT) immunohistochemistry in glioblastoma multiforme: observer variability and lack of association with patient survival impede its use as clinical biomarker. Brain Pathol 2008; 18: 520-32

147 Gilbert MR, Wang M, Aldape KD, Stupp R, Hegi ME, Jaeckle KA, Armstrong TS, Wefel JS, Won M, Blumenthal DT, Mahajan A, Schultz CJ, Erridge S, Baumert B, Hopkins KI, TzukShina T, Brown PD, Chakravarti A, Curran WJ, Jr., Mehta MP. Dose-dense temozolomide for newly diagnosed glioblastoma: a randomized phase III clinical trial. J Clin Oncol 2013; 31: 4085-91 
148 Jeuken JW, Cornelissen SJ, Vriezen M, Dekkers MM, Errami A, Sijben A, BootsSprenger SH, Wesseling P. MS-MLPA: an attractive alternative laboratory assay for robust, reliable, and semiquantitative detection of MGMT promoter hypermethylation in gliomas. Lab Invest 2007; 87: 1055-65

149 Wojdacz TK, Dobrovic A. Methylation-sensitive high resolution melting (MS-HRM): a new approach for sensitive and high-throughput assessment of methylation. Nucleic Acids Res 2007; 35: e41

150 Smith JS, Perry A, Borell TJ, Lee HK, O'Fallon J, Hosek SM, Kimmel D, Yates A, Burger PC, Scheithauer BW, Jenkins RB. Alterations of chromosome arms $1 p$ and $19 q$ as predictors of survival in oligodendrogliomas, astrocytomas, and mixed oligoastrocytomas. J Clin Oncol 2000; 18: 636-45

151 Ichimura K, Vogazianou AP, Liu L, Pearson DM, Backlund LM, Plant K, Baird K, Langford CF, Gregory SG, Collins VP. 1 p36 is a preferential target of chromosome 1 deletions in astrocytic tumours and homozygously deleted in a subset of glioblastomas. Oncogene 2008; 27: 2097-108

152 Lee D, Cho YH, Kang SY, Yoon N, Sung CO, Suh YL. BRAF V600E mutations are frequent in dysembryoplastic neuroepithelial tumors and subependymal giant cell astrocytomas. J Surg Oncol 2014:

153 von Deimling A, Korshunov A, Hartmann C. The next generation of glioma biomarkers: MGMT methylation, BRAF fusions and IDH1 mutations. Brain Pathol 2011; 21: 74-87

154 Venneti S, Felicella MM, Coyne T, Phillips JJ, Gorovets D, Huse JT, Kofler J, Lu C, Tihan T, Sullivan LM, Santi M, Judkins AR, Perry A, Thompson CB. Histone 3 lysine 9 trimethylation is differentially associated with isocitrate dehydrogenase mutations in oligodendrogliomas and high-grade astrocytomas. J Neuropathol Exp Neurol 2013; 72: 298-306 155 Hegi ME, Liu L, Herman JG, Stupp R, Wick W, Weller M, Mehta MP, Gilbert MR. Correlation of O6-methylguanine methyltransferase (MGMT) promoter methylation with clinical outcomes in glioblastoma and clinical strategies to modulate MGMT activity. J Clin Oncol 2008; 26: 4189-99 